\title{
Teacher Unions, Teacher Pay and Student Performance in India: A Pupil Fixed Effects Approach
}

\author{
GEETA KINGDON \\ FRANCIS TEAL
}

CESIFO WORKING PAPER No. 2428

CATEGORY 4: LABOUR MARKETS

OCTOBER 2008
An electronic version of the paper may be downloaded
- from the SSRN website:
- from the RePEc website:
- from the CESifo website:
www.SSRN.com
www.RePEc.org
www.CESifo-group.org/wp




\title{
Teacher Unions, Teacher Pay and Student Performance in India: A Pupil Fixed Effects Approach
}

\begin{abstract}
This paper examines the relationship between teacher unionization, student achievement and teachers' pay using a cross-section of data from private schools in India. We use differences in student mark across subjects to identify within-pupil variation in achievement and find that union membership of the teacher appears to strongly reduce pupil achievement. We find no evidence this could be due to the unobservables not controlled for by this procedure. A school fixed effects equation of teacher pay shows that union membership substantially raises pay and in this case too we find that remaining unobservables are unlikely to explain this outcome. We thus have in this data clear evidence that unions raise cost and reduce student achievement.
\end{abstract}

JEL Code: I21.

Keywords: teacher unions, teacher salaries, student achievement, productivity, India.

\author{
Geeta Kingdon \\ Institute of Education \\ London University \\ 20 Bedford Way \\ London WC1H OAL \\ United Kingdom \\ g.kingdon@ioe.ac.uk
}

\author{
Francis Teal \\ Department of Economics \\ University of Oxford \\ Manor Road \\ Oxford, OX1 3UQ \\ United Kingdom \\ francis.teal@economics.ox.ac.uk
}

September 2008

This paper was presented to the Conference on 'Economic Incentives: Do They Work in Education?' 15-17 May 2008 jointly organised by CESifo and PEPG (Program on Education Policy and Governance), Kennedy School of Government, Harvard University.

This paper has benefited from the comments of Joshua Angrist, Martin Browning, Paul Collier, Esther Duflo, Paul Glewwe, Eric Hanushek, Helen Ladd, Stephen Machin, Lant Pritchett, Måns Söderbom and Alessandro Tarozzi, as well as the comments of participants at the NEUDC, Royal Economic Society and CES-ifo/PEPG conferences. We are greatly indebted to Todd Elder for sharing STATA routines with us. Any errors are ours. We would like to thank the Council for Indian Secondary Certificate Examinations for enabling data collection from affiliated schools. Funding from ESRC Global Poverty Research Group and the DFID RECOUP consortium on 'Outcomes of Education' is gratefully acknowledged. 


\section{$1 \quad$ Introduction}

Under different theoretical models, teacher unionization can lead to higher or lower student achievement. Conceptually there are two major reasons why teachers may become union members (Hoxby, 1996). The first is that teachers maximise the same objective function as parents, namely student achievement, but have superior information about the correct input mixes. Union membership provides teachers with a collective voice to implement these input mixes. This may include for instance asking for lower class sizes or higher salaries which help to attract and retain superior teachers. The second potential reason for teachers joining a union is that they have a different objective function than parents or school management, possibly one in which school policies that directly affect them, such as teacher salaries, receive greater weight than policies that only indirectly affect them, i.e. membership of a rent-seeking teachers’ union ${ }^{1}$. A rent-seeking union may block reform of incentives to improve instruction, e.g. by tying salaries to seniority rather than to performance and by protecting ineffective teachers from dismissal. Under rent seeking, unions may also lower achievement if their pursuit of higher salaries diverts resources away from other school inputs that raise achievement and if teacher union strikes

${ }^{1}$ Loveless (2000), Ballou (2001) and Ballou and Podgursky (2000) argue that unions retard school reform. On the other hand, Henderson, Urban and Wolman (2004) argue that in recent times the public "has been exposed to a barrage of pejorative views" about teacher unions which "by and large condemn unions as obstacles to efficiency and quality” but do not recognise what unions have contributed towards building a quality public education system. Stone (2000) and Eberts (2007) summarize the US literature on the effect of teacher unions on student achievement. 
disrupt teaching. Finally, since teachers interact with other inputs in order to produce education, rent seeking unions could lower the efficiency of the other inputs, such that more money for schools may not matter (Burtless, 2000; Lemke, 2004; Hoxby, 1996).

The sign of the relationship between teacher union membership and student achievement is thus an empirical question. This paper addresses this empirical question asking how teacher unions affect student achievement and teacher's pay. We pose these questions with a unique dataset on private secondary schools from India which permits pupil fixed effects estimation of the achievement function, enabling us to address what are arguably the most important sources of endogeniety bias.

As has been widely recognised in the achievement production function literature, imputing causality from any cross-section correlation between teacher attributes and student outcomes is problematic as students may match to schools and teachers endogenously. While randomized experiments provide a good solution to the problem of endogeneity in general (see Duflo and Hanna, 2005, for one educational application in India), they cannot be used here since union membership cannot be randomly allocated. Although quasi-experimental approaches such as propensity score matching methods have been used to evaluate education program impacts (e.g. Machin and McNally, 2004), they require the assumption that matching based on pretreatment observables adequately captures all relevant characteristics of treated units. Valid instrumental variables are difficult to find and only few studies have convincingly tested impact effects in education using the IV approach (e.g. Angrist and Lavy,1999). The IV approach is often infeasible in developing countries because even where official (exogenous) rules, e.g. about maximum class-size or school start age etc., exist in law, they are rarely adhered to in practice. The panel data approach requires longitudinal data and this is scarce. 
We examine the effect of teacher union membership on pupil learning using the standard cross-section achievement production function but allowing for pupil fixed effects. This is possible because the data used here provide each student's marks in five different subjects (English, second language, history/geography, math, science). We link the average characteristics of the teachers who teach that subject within the school to the achievement of the student. This approach allows us to control for all student and family unobservables and examine whether the union membership status of different subject teachers in a school is related to a student's marks across those subjects. In other words, we estimate a within-pupil across-subject equation of the achievement production function rather than a within-pupil across-time one. After investigating the union effect on pupil learning, we also examine the teacher pay schedule to ask whether unionized teachers are paid more once we control for their observable skills and the unobservable characteristics of the school. ${ }^{2}$

While the above approach can control for many possible sources of endogeneity, it cannot control for all. To see if the remaining unobservables could be explaining our results, we adopt the procedure developed by Altonji, Elder and Taber (2005) to assess how important these unobservables would need to be to explain our result. How important unobservables will be depends on what we can observe so in the next section we set out the data and model explicitly the potential role of unobservables in explaining our results. Section 3 presents estimates of how

\footnotetext{
${ }^{2}$ While much has been written on the effect of teacher unions on student achievement in the US, both by economists and non-economists (Eberts and Stone, 1987; Betts, 1996; Hoxby, 1996; Ballou and Podgursky, 2000; Lemke, 2004; Eberts, 2007; Loveless, 2000; Carini, 2002; Henderson, Urban and Wolman, 2004), we are not aware of any research on this topic in developing countries in general and in India in particular.
} 
union membership affects achievement and section 4 the results for the effect of union membership on teacher pay. A final section concludes.

\section{Observables and Unobservables for Student Achievement}

The data for this study come from a sample of 186 schools affiliated to the Council for Indian Secondary Certificate Examinations (CISCE) which is an English Medium exam board. The schools were chosen by a stratified random sampling procedure within 16 major Indian states (the strata). The sampling procedure is explained in Kingdon (2006). Postal questionnaires sent by the Exam Board were filled by all students of grade 10 in the sample schools, and by the teachers that teach them, as well as by the school Principal. Grade 10 students are aged approximately 16 years old and the grade 10 board examination in CISCE schools is equivalent to the High School board examination in other Indian exam boards, such as the state examination boards or the Central Board of Secondary Education. The overwhelming proportion of CICSE affiliated schools are private unaided schools, i.e. run without state aid (95\%), 3.2\% are aided schools (mainly in West Bengal), and only $1.6 \%$ are government or local body schools. Thus the sample represents mainly English Medium private secondary schools in India.

The student questionnaire captured information on a wide range of the child's personal characteristics including age, gender, health, disability, and time-use, as well as detailed family characteristics such as household demographics, asset/wealth ownership, parental education and occupation. Pupils were also given a test of ability/IQ based on 36-items in Sets A, C and D of the Ravens Progressive Matrices test. The teacher questionnaire collected information on a range of teacher characteristics and the school questionnaire elicited data on student and teacher numbers, school facilities and resources, length of the instructional program, school fees, and management and teacher motivation aspects. 
Examination results data were subsequently provided by the exam board and matched to students using a unique pupil identifier code. Students of grade 10 in the CISCE exam board have 5 compulsory and one optional subject. The optional subject is chosen from among a large number of subject choices and thus varies a great deal between students. We wish to use exam marks of students in the 5 compulsory subjects: English, Second language, History/Geography, Math and Science ${ }^{3}$. Table 1 shows mean mark by subject. Figure 1 shows Epanechnikov kernel densities of marks in different subjects. It is clear that the distribution of marks in different subjects differs appreciably. For instance, the distribution of the second-language mark is quite different to that of other subjects. In order to render the marks in the different subjects comparable, we standardize the mark in each subject by the national mean mark in the subject, i.e. we use the z-score of achievement as our dependent variable. The z-score is a student's mark in a subject less the national mean mark in that subject, divided by the standard deviation of mark in the subject. Thus, by construction, mean $\mathrm{z}$ score in any given subject is 0 and its standard

\footnotetext{
${ }^{3}$ As the ICSE exam board is an English Medium exam board, all subjects in affiliated schools are taught in English. The local state language is considered the 'Second language' and it is typically a child's mother tongue. While History and Geography are tested separately, their marks are pooled by the examination board and provided together, i.e. they are treated as one subject. Similarly, while physics, chemistry and biology are tested separately, their marks are lumped together. When matching student marks in a subject to the characteristics of the teacher that taught them that subject, we have taken the average characteristics of the teachers that taught them that subject. Thus, if history and geography were taught to grade 10 by different teachers, we have taken the average characteristics of the history and geography teachers as the relevant characteristics to match with a student's history-geography subject-row.
} 
deviation is 1 . Figure 2 shows the distribution of z-score for all subjects. Appendix Table 1 defines variables and shows descriptive statistics. The OLS regressions of standardized achievement by subject are presented in Appendix Table 2, as an extension of the descriptive statistics, but we do not discuss these.

As a result of this data collection we have marks across subjects for the same student within a school as well as an extensive range of controls for both the student and the teacher. We have taken the average of characteristics of the subject teachers within a school so we have variation in these characteristics for a student across subjects. It is this cross-subject variation we intend to exploit in establishing if there is an effect from unions onto student achievement.

$$
A_{i j k}=\alpha+\beta X_{i j}+\gamma T_{j k}+\delta S_{j}+\left(\mu_{i}+\varepsilon_{j}+\eta_{k}\right)+v_{i j k}
$$

$A_{i j k}$ is achievement of the $i^{\text {th }}$ student in the $j^{\text {th }}$ school in the $k^{\text {th }}$ subject, $X$ is a vector of characteristics of the $i^{\text {th }}$ student in the $j^{\text {th }}$ school, $T$ a vector of characteristics (including union membership) of the teacher of the $j^{\text {th }}$ school for subject $k$ and $S$ a vector of characteristics of the $j^{\text {th }}$ school. $\mu_{i}, \varepsilon_{j}$ and $\eta_{k}$ represent the unobserved characteristics of the student, the school and the subject respectively. The remaining unobservables are in the error term, $v_{i j k}$, and it is their potential correlation with the observables, in particular the union variable, that is the key to being able to identify a causal effect from unionization onto achievement. We proceed by seeking to identify the Union effect separately from the other teacher characteristics which we treat as controls:

$$
A_{i j k}=\alpha+\beta X_{i j}+\gamma T C_{j k}+\theta U_{j k}+\delta S_{j}+\left(\mu_{i}+\varepsilon_{j}+\eta_{k}\right)+v_{i j k}
$$

where $T C_{j k}$ is all teacher characteristics that are independent of the unionization term, $U_{j k}$. The teacher's characteristics that we are going to use in our achievement production function are: 


$$
T C_{j k}=\left\{\text { High }_{j k}, \text { Train }_{j k}, \text { Divison }_{j k}, \text { Christian }_{j k}, \text { Female }_{j k}, \text { Age }_{j k}\right\}
$$

where $\mathrm{High}_{j k}$ is whether the teacher has a higher qualification meaning an MA or $\mathrm{PhD}$ qualification, $\operatorname{Train}_{j k}$ is whether the teacher has pre-service teacher training, Division $_{j k}$ is whether the teacher had obtained first division in his/her higher secondary exam (a proxy for teacher's own cognitive skills), Christian $_{j k}$ is whether the teacher is a Christian, Female ${ }_{j k}$ indicates their gender and $A g e_{j k}$ their age. All these characteristics can be viewed as pre-determined for the union variable. We also have information on other teacher characteristics which arguably may not be. We denote these as $T C_{j k}^{\prime}$ :

$$
T C_{j k}^{\prime}=\left\{\text { Leave }_{j k}, \text { Experience }_{j k}, \text { Tenure }_{j k}, \text { Permanent }_{j k}\right\}
$$

where Leave $_{j k}$ is the days of sick leave last year, Experience $_{j k}$ is the total years of teaching experience, Tenure $_{j k}$ is years of tenure in current school and Permanent ${ }_{j k}$ is whether the teacher has a permanent position. All the arguments of $T C_{j k}^{\prime}$ arguably may be at least in part determined by the union status of the teacher so including them in the student achievement function would bias down the effect of unionization. To test whether our results are sensitive to their inclusion we report regressions which include the arguments of both $T C_{j k}$ and $T C_{j k}^{\prime}$. We apply a similar argument to our equation for Teacher’s pay

(5) $\quad P_{j k}=\phi\left\{T C_{j k}\right\}+\varphi U_{j k}+u_{j k}$

where $P_{j k}$ is the pay of the teacher. If we wish to identify the effect of unionization on pay it seems necessary to exclude variables from the regression which, arguably, are in part determined by unionization. Again we test if our results are sensitive to the exclusion of the variables in the $T C_{j k}^{\prime}$ vector. 
Equations (2) and (5) are our equations of interest and for both we need to allow for the possibility that there remain unobservables in the error terms correlated with the union variable. Before considering this problem we outline how across-subject differencing has two important methodological advantages over across-time differencing.

Firstly, the across-subject approach does not suffer from the problem of non-random attrition of teachers and students over time that occurs in panel data. For instance, in their panel study relating student achievement to teacher characteristics using North Carolina data, Clotfelter, Ladd and Vigdor (2006) highlight the difficulty of determining whether a higher coefficient on teacher experience reflects a teacher's improved effectiveness with experience or the differentially higher attrition of the less effective teachers ${ }^{4}$, and Rivkin et al (2005) also address non-random attrition. Across-subject estimation obviates this problem since estimation is within pupil at one point in time. While the potential for endogenous selection into the 'surviving' teachers' group is the same in both approaches, the across-time technique relies on change in teacher over time (over which non-random attrition can take place) as part of the estimation strategy, while the across-subject technique does not.

The second methodological advantage is that the across-subject approach provides a means to circumvent the potential problem of non-random matching of students to particular teachers within the school on the basis of their unobserved characteristics - whether it be brighter students matching to abler teachers or school policy deliberately matching slower students to abler teachers. Across-subject estimation bypasses the problem either by averaging the

\footnotetext{
${ }^{4}$ They say that due to the technical difficulty of including both pupil and teacher fixed effects in one equation they attempt to address the problem by using the sub-sample of teachers who remain teachers for three or more years.
} 
characteristics of all teachers by grade and subject within the school, or by restricting the sample to schools where any given subject is taught to the student's grade by only one teacher within the school. Either way, the student is by construction matched to a single set of teacher characteristics in each subject within the school.

It however remains the case that subject-varying school unobservables remain in the error term and may be correlated with the Union variable. Moreover, it is required that teachers' unobserved characteristics be unrelated to the union variable. Since such omitted characteristics may be correlated both with Unionization status and with student achievement we cannot say that pupil fixed effects estimation of achievement - even with no subject-specific student and school unobserved heterogeneity - permits us to interpret the effects of Unionization as causal.

We propose to address this issue by borrowing from the procedures set out in Altonji, Elder and Taber (2005) to assess the potential size of any bias due to the unobservables in the equation (an appendix summarises their algebra which we use below) . In their paper they show that the notion that "selection on observables is the same as selection on unobservables" is equivalent to a condition that in our model (where we drop subscripts for clarity) is:

$$
\frac{\operatorname{Cov}(v, U)}{\operatorname{Var}(v)}=\frac{\operatorname{Cov}(\gamma T C, U)}{\operatorname{Var}(\gamma T C)}
$$

The asymptotic bias from OLS is $\frac{\operatorname{Cov}(v, \tilde{U})}{\operatorname{Var}(\tilde{U})}$, which is equivalent to $\frac{\operatorname{Cov}(v, U)}{\operatorname{Var}(\tilde{U})}$ if $v$ and TC are orthogonal (tildes over a variable denote the residuals from a regression of that variable onTC. We can estimate this bias by noting that:

$$
\begin{aligned}
& \frac{\operatorname{Cov}(v, U)}{\operatorname{Var}(\tilde{U})}=\frac{\operatorname{Cov}(v, U)}{\operatorname{Cov}(\gamma T C, U)} \frac{\operatorname{Var}(\gamma T C)}{\operatorname{Var}(v)} \frac{\operatorname{Cov}(\gamma T C, U)}{\operatorname{Var}(\gamma T C)} \frac{\operatorname{Var}(v)}{\operatorname{Var}(\tilde{U})} \\
& \frac{\operatorname{Cov}(v, U)}{\operatorname{Var}(\tilde{U})}=\frac{\operatorname{Cov}(\gamma T C, U)}{\operatorname{Var}(\gamma T C)} \frac{\operatorname{Var}(v)}{\operatorname{Var}(\tilde{U})}
\end{aligned}
$$


where (8) follows from (7) using (6).

In reporting our regression results we will also show the results from applying this method. We do this by reporting the estimate of bias from equation (8). As we will show, for the school and student fixed effects regressions, the sign of the union effect is negative while the estimate of the potential bias induced by a correlation between the unobservables and the Union variable is positive. In this case the evidence points to the school and student fixed effects estimates of the union membership effect as being underestimates of the true negative impact. Where the sign of the effect and the bias are the same we report their ratio as this is open to the interpretation from Altonji, Elder and Taber (2005) that it measures the size of the shift in the distribution of the unobservables necessary to explain away the implied effect from the Union treatment. We turn now to assessing the role of both observables and unobservables in determining student achievement.

\section{The Achievement Production Function}

The main result of the paper for student achievement is presented in Table 2, which pools all five subjects. In the top panel the only teacher characteristic included is teacher union membership, in the bottom panel we include those teacher covariates in the vector $T C_{j k}$ set out above. The first column is an OLS achievement production function with state dummy variables. The second and third columns show school and pupil fixed effects results. The school fixed effects equation includes the full set of pupil characteristics, including a measure of pupil ability (as measured by the ravens progressive matrices test). The achievement production function changes dramatically when moving from the OLS (Column 1) to the within school analysis of Column (2). Exploiting within pupil variation in Column (3) does not change the union effect significantly. 
In the top panel of Table 2, the coefficient on the union membership variable changes sign from positive to negative as we move from OLS to within-school analysis. While higher scoring schools are more likely to have unionized teachers, within a school the students of unionized teachers have sharply lower achievement levels. The bottom panel which includes the teacher covariates from $T C$ shows a larger negative effect of unionization on achievement. These teacher characteristics do have a highly significant effect on student achievement and are positively correlated with the Union variable. Thus controlling for these observable aspects of the teacher increases the adverse effect of unionization on achievement. These results suggest that the achievement of a student in a subject that is taught by a unionized teacher is 0.23 standard deviations lower than his/her achievement in a subject taught by a non-unionized teacher. Having a unionized teacher appears inimical to student achievement.

The results from the procedures of Altonji, Elder and Taber (2005) are shown in the bottom part of the Table. There is evidence of a potentially substantial bias in the OLS results. However once we move to the school and student fixed effects results, we find evidence of a positive correlation between the unobservables in the achievement equation and the Union variable, implying that the negative effect of Unionization on achievement is underestimated ${ }^{5}$.

Table 3 tests whether our results are sensitive to the inclusion of experience, tenure, permanent status and days of leave taken (arguments in equation (4)), which may be at least in part determined by the union status of the teacher. The inclusion of these variables does not affect the coefficient on union membership much.

Table 4 shows various other robustness tests on the union membership effect. Though the magnitude of the coefficient on the union membership variable varies by sub-sample, it is

\footnotetext{
${ }^{5}$ See the Appendix for the equation of union membership on the $T C$ vector of variables.
} 
negative and statistically significant in virtually all sub-samples, defined by student's gender, religion, wealth and ability, and by political leaning of the state, degree of school competition and subject-combination used for differencing. Unions reduce achievement across the whole range of student ability (lowest quartile, middle 50\% and the top quartile of achievers), though the coefficient is much smaller for low achievers than for middle and high achievers ${ }^{6}$.

As a final robustness check we present in Table 5 the achievement equation on the subsample of schools that had any unionized teachers, which increases the proportion of the sample of children taught by a unionized teacher to 37 per cent. The coefficient on the union membership variable is very similar to that in Table 3 . Table 5 also shows that teachers' possession of MA qualifications and teachers' cognitive skills (proxied by first division in board exam) raise student achievement only in the non-unionized schools, i.e. the productivity of teacher characteristics is greater in non-union schools, a result similar to that in Hoxby (1996) where the beneficial effects of school inputs (such as lower class-size) and of teacher salary on pupil achievement are significantly lower in unionized than in non-unionized school districts.

\section{$4 \quad$ Teacher pay schedule}

How do unions impact on pay? We attempt to answer this question by examining the teacher pay schedule. All employers with more than 10 workers in India have to de jure abide by minimum wage laws and 'recognized' private schools are required to pay teachers salaries on a par with the government teacher salary scales. De facto, many private schools pay teachers significantly less

\footnotetext{
${ }^{6}$ This contrasts somewhat with syntheses of the US literature which find that unions modestly improve the achievement level of students who are middle-range performers but reduce that of students who are low and high performers (Eberts, 2007; Stone, 2000; Carini, 2002; Betts, 1996).
} 
than the government prescribed minima. For instance, at the middle school level, Kingdon (1996) found that private teachers' mean salary was only $60 \%$ of the public teachers' mean salary. Kingdon and Teal (2007) confirm that salary structures in public and private schools in India are very different.

The survey for this study collected information on all teachers that taught grade 10 students in sample schools. This yielded a sample of 2103 teachers of whom 1731 are teachers of the five compulsory subjects taught at grade 10 level. The first column of Table 6 presents an OLS equation of log of teacher pay but our data also have within-school variation in teacher pay, which is used to estimate a school fixed effects equation in column 2. The coefficients on some of the variables - and especially on the union membership variable - change when moving from across to within school estimation. Since teachers may sort into schools on the basis of their unobserved characteristics, we rely more on the school fixed effects regression in the second column.

The variable of interest is union membership. It is seen that the coefficient on union membership is positive and statistically significant at the $5 \%$ level. Within a school, a union member earns a wage premium of $14.9 \%$ over non-union members. This regression does not control for the teacher characteristics identified above as potentially determined by unionization. If we include these, the union effect falls to $9.5 \%$ as is shown in Table 7 . This is similar to the teacher union wage effect of 7.6\% estimated by Lemke (2004) for Pennsylvania using data from school districts after accounting for aspects of teacher quality. It is also virtually identical to the union wage effect of 8-10\% associated with other US public sector unions.

Applying a similar test for the importance of unobservables to those already reported for the achievement equations, we do now find a positive potential bias on the positive union coefficient, but it is small compared with the size of the union pay effect. The ratio of effect to 
bias is 1.65 which implies that the role of unobservables that determine pay would have to be more than 1.65 times the role of observables for the entire union pay effect to be explained away by the unobservables, which seems unlikely given the rich set of observables we include, including the school fixed effects. This suggests that part of the union pay effect is real.

\section{Conclusions}

Using a methodology for identification that allows for controls at the level of the pupil, we find that the achievement level of a student in a subject that is taught by a unionized teacher is about a quarter of a standard deviation lower than his/her achievement in a subject that is taught by a non-unionized teacher. A school fixed effects equation of teacher pay shows that union membership is rewarded with substantially higher pay. In other words, union membership of teachers reduces student achievement and raises salary costs in private schools in India.

While we controlled for what are commonly regarded as the most important sources of omitted variable bias in the student achievement equation - namely the non-random matching of students to schools and teachers on the basis of their unobserved characteristics, teacher unobservables are still in the error term and could be related with observed teacher characteristics. We sought to deal with this potential source of bias by using the method of Altonji, Elder and Taber (2005) and find, once we allow for school or student fixed effects, that the negative union effect on student achievement is, if anything, underestimated. For the teacher pay equation we find, using a similar method, that it is unlikely that the positive effect of union on pay can be explained away by bias due to unobservables. 


\section{References}

Altonji, J., T. Elder and C. Taber (2005) "Selection on Observed and Unobserved Variables: Assessing the Effectiveness of Catholic Schools,” Journal of Political Economy, 113 (1): 151184, February.

Angrist, J. and V. Lavy (1999) “Using Maimonides' Rule to Estimate the Effect of Class Size on Scholastic Achievement”, Quarterly Journal of Economics, 114(2): 533-75.

Ballou, D. (2001). Pay for performance in public and private schools, Economics of Education Review, 20, pp. 51-61.

Ballou, D. and M. Podgursky (2000) "Teacher Unions and Education Reform: Gaining Control of Professional Licensing and Advancement." in Tom Loveless (ed.) Conflicting Missions: Teacher Unions and Education Reform. Washington DC: The Brookings Institution.

Betts, Julian (1996) "Is there a link between school inputs and earnings? Fresh scrutiny of an old literature” in Burtless, G. (ed.) “Does Money Matter? The Effect of School Resources on Student Achievement and Adult Success”, Brookings Institution Press.

Burtless, G. (2000) “Does Money Matter? The Effect of School Resources on Student Achievement and Adult Success”, Brookings Institution Press. 
Carini, Robert M. 2002. “Teacher Unions and Student Achievement.” Pp. 197-215 in School Reform Proposals: The Research Evidence, edited by Alex Molnar. Greenwich, CT: Information Age Publishing.

Clotfelter, C., H. Ladd and J. Vigdor (2006) “Teacher-Student Matching and the Assessment of Teacher Effectiveness”, NBER Working Paper No. 11936, January.

Duflo, Esther and Rema Hanna (2005) "Monitoring Works: Getting Teachers to Come to School”, mimeo, Poverty Action Lab, Massachusetts Institute of Technology. September.

Eberts, R. W. and J. A. Stone (1987) “The effect of teacher unions on student achievement”, Industrial and Labor Relations Review, 40 (3): 354-363. April.

Eberts, Randall (2007) “Teacher unions and student performance: Help or hindrance?”, The Future of Children, 17 (1): 175-200. Spring.

Henderson, Urban and Wolman (2004) Teacher Unions and Education Policy: Retrenchment or Reform? Oxford. Elsevier.

Hoxby, C. (1996) “How teachers’ unions affect education production”, Quarterly Journal of Economics, 111 (4): 671-718.

Kingdon, G. G. (1996) “The Quality and Efficiency of Public and Private Schools: A Case Study of Urban India”, Oxford Bulletin of Economics and Statistics, 58, No.1: 55-80, Feb. 1996. 
Kingdon, G. G. and F. Teal (2007) "Does Performance Related Pay for Teachers Improve Student Achievement? Some Evidence from India”, Economics of Education Review, 26, No. 4 : 473-86. August 2007.

Lemke, R. (2004) "Estimating the union wage effect for public school teachers when all teachers are unionized”, Eastern Economic Journal, 30(2): 273-91. Spring.

Loveless, T. (ed.) (2000) Conflicting missions? Teachers unions and educational reform. Washington, DC: Brookings Institution.

Machin, S. and S. McNally (2004) “The Literacy Hour”, Discussion Paper CEE 0043, Centre for Economics of Education, London School of Economics.

Rivkin, S., E. Hanushek and J. Kain (2005) “Teachers, Schools and Academic Achievement”, Econometrica, 73(2): 417-58. 
Table 1

Mean and standard deviation of raw mark, by subject

\begin{tabular}{lcccc}
\hline \multicolumn{1}{c}{ Subject } & Mean mark & SD & Minimum & Maximum \\
\hline English & 67.15 & 15.3 & 20 & 97 \\
Second language & 79.73 & 8.9 & 28 & 99 \\
History-geography & 70.09 & 14.3 & 20 & 99 \\
Math & 68.92 & 18.4 & 15 & 99 \\
Science & 65.72 & 17.0 & 20 & 99 \\
\hline
\end{tabular}

Note: Descriptive statistics of standardized mark by subject are not reported as, by construction, the mean of standardized mark is 0 and standard deviation is 1 for each subject. 
Table 2

Achievement production function

Panel A : 'member of a union' as the only included variable

\begin{tabular}{lccc}
\hline & OLS & School FE & Pupil FE \\
\hline Member of union & $0.1816^{* *}$ & $-0.1755^{* *}$ & $-0.1671^{* *}$ \\
& $(4.22)$ & $(-5.28)$ & $(-5.05)$ \\
\hline Subject dummies & yes & yes & yes \\
Pupil variables & yes & yes & no \\
School variables & yes & no & no \\
$\mathrm{N}$ & 49089 & 49089 & 49089 \\
R-squared & 0.26 & 0.35 & --- \\
Number of clusters & 16 & 172 & 10016 \\
F (p-value) & $90.36(0.000)$ & $58.06(0.000)$ & $12.29(0.000)$ \\
\hline
\end{tabular}

Panel B: Including pre-determined teacher characteristics (TC)

\begin{tabular}{lccc}
\hline & OLS & School FE & Pupil FE \\
\hline Member of union & $0.1788^{* *}$ & $-0.2342^{* *}$ & $-0.2266^{* *}$ \\
& $(4.17)$ & $(-6.91)$ & $(-6.72)$ \\
MA or PhD qualification & $0.1206^{* *}$ & $0.0929^{* *}$ & $0.0914^{* *}$ \\
& $(9.07)$ & $(9.63)$ & $(9.58)$ \\
Pre-service teacher training & $0.0602^{* *}$ & $0.0871^{* *}$ & $0.0885^{* *}$ \\
& $(4.66)$ & $(10.0)$ & $(10.2)$ \\
First division in hisec exam & $0.1020^{* *}$ & $0.1092^{* *}$ & $0.1053^{* *}$ \\
& $(5.35)$ & $(7.74)$ & $(7.52)$ \\
Christian & 0.0214 & $0.0254^{*}$ & $0.0252^{*}$ \\
& $(1.43)$ & $(2.49)$ & $(2.49)$ \\
Female & $-0.0384^{* *}$ & 0.0039 & 0.0020 \\
& $(-2.74)$ & $(0.40)$ & $(0.21)$ \\
Age & $0.0459^{* *}$ & $0.0272^{* *}$ & $0.0260^{* *}$ \\
& $(10.2)$ & $(8.69)$ & $(8.38)$ \\
Age square & $-0.0005^{* *}$ & $-0.0003^{* *}$ & $-0.0003^{* *}$ \\
& $(-9.51)$ & $(-8.21)$ & $(-7.84)$ \\
\hline Subject dummies & yes & yes & yes \\
Pupil variables & yes & yes & -- \\
School variables & yes & -- & -- \\
Observations & 49089 & 49089 & 49089 \\
R-squared & 0.27 & 0.35 & --- \\
Number of clusters & 16 & 172 & 10016 \\
& & & \\
Estimated Bias (Equation (8)) & 0.57 & 0.27 & 0.91 \\
Ratio (a) & 0.31 & -- & -- \\
\hline
\end{tabular}

(a) This is the ratio of the coefficient on union membership and the estimated bias.

Note: Constant included but not shown. Standard errors were corrected for clustering of errors between subjects within a pupil, i.e. we have used pupil id as the clustering variable. In all three columns, the fixed effects (state, school and pupil respectively) were highly statistically significant in F-tests (not shown). ${ }^{* *}$ represents statistical significance at the $1 \%$ level and ${ }^{*}$ at the $5 \%$ level. 
Table 3

Achievement production function

(including the teacher characteristics in $\mathrm{TC}^{\prime}$ )

\begin{tabular}{|c|c|c|c|}
\hline & OLS & School FE & Pupil FE \\
\hline Member of teacher union & $\begin{array}{l}0.1568^{* *} \\
(3.68)\end{array}$ & $\begin{array}{c}-0.2436^{* *} \\
(-7.14)\end{array}$ & $\begin{array}{c}-0.2347^{* *} \\
(-6.91)\end{array}$ \\
\hline MA or PhD qualification & $\begin{array}{l}0.1272^{* *} \\
(9.55)\end{array}$ & $\begin{array}{c}0.0934^{* *} \\
(9.52)\end{array}$ & $\begin{array}{l}0.0923^{* *} \\
(9.51)\end{array}$ \\
\hline Pre-service teacher training & $\begin{array}{l}0.0533^{* *} \\
(4.14)\end{array}$ & $\begin{array}{l}0.0900^{* *} \\
(10.3)\end{array}$ & $\begin{array}{l}0.0911^{* *} \\
(10.5)\end{array}$ \\
\hline First division in hisec exam & $\begin{array}{l}0.0979^{* *} \\
(5.14)\end{array}$ & $\begin{array}{l}0.1153^{* *} \\
(8.15)\end{array}$ & $\begin{array}{l}0.1113^{* *} \\
(7.94)\end{array}$ \\
\hline Christian & $\begin{array}{c}-0.0130 * * \\
(-5.99)\end{array}$ & $\begin{array}{c}-0.0053^{* *} \\
(-3.70)\end{array}$ & $\begin{array}{c}-0.0060 * * \\
(-4.21)\end{array}$ \\
\hline Female & $\begin{array}{c}0.0183 \\
(1.21)\end{array}$ & $\begin{array}{c}0.0249 * \\
(2.45)\end{array}$ & $\begin{array}{c}0.0247^{*} \\
(2.45)\end{array}$ \\
\hline Age & $\begin{array}{c}-0.0335^{*} \\
(-2.41)\end{array}$ & $\begin{array}{r}0.0062 \\
(0.64)\end{array}$ & $\begin{array}{r}0.0049 \\
(0.52)\end{array}$ \\
\hline Age square & $\begin{array}{l}0.0271^{* *} \\
(5.53)\end{array}$ & $\begin{array}{l}0.0252^{* *} \\
(7.28)\end{array}$ & $\begin{array}{l}0.0240^{* *} \\
(7.00)\end{array}$ \\
\hline Days of sick leave last year & $\begin{array}{c}-0.0003^{* *} \\
(-5.15)\end{array}$ & $\begin{array}{c}-0.0003^{* *} \\
(-6.71)\end{array}$ & $\begin{array}{c}-0.0002^{* *} \\
(-6.38)\end{array}$ \\
\hline Total experience & $\begin{array}{c}-0.0034 * * \\
(-3.18)\end{array}$ & $\begin{array}{c}-0.0041^{* *} \\
(-5.49)\end{array}$ & $\begin{array}{c}-0.0040 * * \\
(-5.37)\end{array}$ \\
\hline Tenure & $\begin{array}{l}0.0035^{* *} \\
(3.29)\end{array}$ & $\begin{array}{l}0.0030^{* *} \\
(3.99)\end{array}$ & $\begin{array}{c}0.0030 * * \\
(4.07)\end{array}$ \\
\hline Permanent status & $\begin{array}{c}0.1995 * * \\
(9.20) \\
\end{array}$ & $\begin{array}{c}0.0325^{*} \\
(2.36) \\
\end{array}$ & $\begin{array}{c}0.0293^{*} \\
(2.16) \\
\end{array}$ \\
\hline Subject dummies & yes & yes & yes \\
\hline Pupil variables & yes & yes & no \\
\hline School variables & yes & no & no \\
\hline $\mathrm{N}$ & 49089 & 49089 & 49089 \\
\hline R-squared & 0.27 & 0.35 & --- \\
\hline Number of clusters & 16 & 172 & 10016 \\
\hline F (p-value) & $98.3(0.000)$ & $54.5(0.000)$ & $11.3(0.000)$ \\
\hline $\begin{array}{l}\text { Estimated Bias (Equation } \\
\text { (8)) }\end{array}$ & 0.64 & 0.31 & 0.88 \\
\hline Ratio (a) & 0.24 & -- & -- \\
\hline
\end{tabular}

(a) This is the ratio of the coefficient on union membership and the estimated bias.

Note: Constant included but not shown. Standard errors were corrected for clustering of errors between subjects within a pupil, i.e. we have used pupil id as the clustering variable. In all three columns, the fixed effects (state, school and pupil respectively) are highly statistically significant in F-tests. ${ }^{* *}$ represents statistical significance at the $1 \%$ level and ${ }^{*}$ at the $5 \%$ level 
Table 4

Robustness tests - the union coefficient in different samples

\begin{tabular}{|c|c|c|}
\hline & $\begin{array}{c}\text { Coefficient on } \\
\text { union variable }\end{array}$ & $\begin{array}{l}\text { Robust } \\
\text { t-value }\end{array}$ \\
\hline \multicolumn{3}{|l|}{ Pupil's wealth quartile } \\
\hline Bottom quartile & $-0.2070^{* *}$ & -3.86 \\
\hline Top 3 quartiles & $-0.2584^{* *}$ & -5.95 \\
\hline \multicolumn{3}{|l|}{ Pupil's gender } \\
\hline Boys & $-0.2106^{* *}$ & -5.24 \\
\hline Girls & $-0.3830 * *$ & -6.52 \\
\hline \multicolumn{3}{|l|}{ Pupil's religion } \\
\hline Hindu & $-0.2039 * *$ & -5.54 \\
\hline Minority & $-0.3397 * *$ & -4.30 \\
\hline \multicolumn{3}{|l|}{ Student ability } \\
\hline Lowest quartile of total mark & $-0.1081^{*}$ & -1.97 \\
\hline Middle two quartiles of total mark & $-0.2712^{* *}$ & -4.89 \\
\hline Top quartile of total mark & $-0.2206 * *$ & -4.08 \\
\hline \multicolumn{3}{|l|}{ Political leaning of the state ${ }^{(a)}$} \\
\hline Non-Left state & $-0.2187 * *$ & -3.21 \\
\hline Left state & $-0.1497 * *$ & -3.64 \\
\hline \multicolumn{3}{|l|}{ Degree of school competition ${ }^{(b)}$} \\
\hline Low & -0.0943 & -1.26 \\
\hline Medium & $-0.1435 * *$ & -3.10 \\
\hline High & $-0.4637 * *$ & -6.94 \\
\hline \multicolumn{3}{|l|}{ Three subject combinations } \\
\hline English, second language, history-geography & $-0.2942 * *$ & -4.70 \\
\hline English second language, math & $-0.4728 * *$ & -7.92 \\
\hline English, second language, science & $-0.4480 * *$ & -9.25 \\
\hline English, history-geography, math & $-0.0962 *$ & -1.77 \\
\hline English, history-geography, science & $-0.1399 * *$ & -3.03 \\
\hline English, math, science & -0.0353 & -1.02 \\
\hline Second language, history-geography, math & $-0.1481 * *$ & -2.93 \\
\hline Second language, history-geography, science & $-0.1883 * *$ & -4.99 \\
\hline History-geography, math, science & $-0.4429 * *$ & -11.01 \\
\hline \multicolumn{3}{|l|}{ Four subject combinations } \\
\hline English, second language, history-geography, math & $-0.2569 * *$ & -5.59 \\
\hline English, second language, history-geography, science & $-0.2566 * *$ & -6.94 \\
\hline English, history-geography, math, science & $-0.1049 * *$ & -2.74 \\
\hline English, second language, math, science & $-0.2006 * *$ & -6.04 \\
\hline Second language, history-geography, math, science & $-0.3431 * *$ & -8.47 \\
\hline
\end{tabular}

Notes: All equations estimated using the pupil fixed effects estimator and using the exact specification of column 3 in the bottom panel (panel B) of Table 2, i.e. including controls for teacher variables. ${ }^{* *}$ represents statistical significance at the $1 \%$ level and * at the $5 \%$ level. 
(a) 'Left leaning' states are West Bengal and Kerala, which have had communist parties in power in much of the post-independence period. The lower effect of teacher union-membership in the 'Left' states may be because in their stronger pro-labour environment, teacher demands are satisfied without unionized teachers losing teaching days through strike action.

(b) School competition is measured by the number of schools situated within a $5 \mathrm{~km}$ radius of the school. Fewer than 4 nearby schools corresponds to 'low' and greater than 12 corresponds to 'high' competition. Union effects are greatest in high competition schools, perhaps because unionized teachers are less afraid of rent-seeking/shirking in high school concentration areas, where the teacher labor market is tighter and the prospect of getting other teaching jobs is greater.

Table 5

Pupil fixed effects achievement equation, on sub-sample of unionized schools

\begin{tabular}{lcc}
\hline & All schools§ & Unionized schools \\
\hline Member of union & $-0.2266^{* *}$ & $-0.2428^{* *}$ \\
MA or PhD qualification & $(-6.72)$ & $(-5.94)$ \\
& $0.0914^{* *}$ & $-0.0631^{*}$ \\
Pre-service teacher training & $(9.58)$ & $(-2.10)$ \\
& $0.0885^{* *}$ & $0.0793^{* *}$ \\
First division in hisec exam & $(10.2)$ & $(3.52)$ \\
& $0.1053^{* *}$ & $-0.1247^{*}$ \\
Christian & $(7.52)$ & $(-2.56)$ \\
& $0.0252^{*}$ & -0.0604 \\
Female & $(2.49)$ & $(-1.79)$ \\
& 0.0020 & $-0.2096^{* *}$ \\
Age & $(0.21)$ & $(-7.88)$ \\
& $0.0260^{* *}$ & 0.0261 \\
Age square & $(8.38)$ & $(1.61)$ \\
& $-0.0003^{* *}$ & -0.0003 \\
Subject dummies & $(-7.84)$ & $(-1.34)$ \\
Observations & yes & Yes \\
Number of clusters (i.e. pupils) & 49089 & 4790 \\
\hline
\end{tabular}

Notes: $\S$ these are results for the whole sample, taken from the last column of Table $2 \mathrm{~b}$. ** represents statistical significance at the $1 \%$ level and ${ }^{*}$ at the $5 \%$ level. 
Table 6

Regression of log of teacher's monthly pay

(Teachers of grade 10 who teach the 5 main subjects only)

\begin{tabular}{|c|c|c|}
\hline & $\begin{array}{c}\text { Across school } \\
(\mathrm{OLS})\end{array}$ & $\begin{array}{c}\text { Within school } \\
\text { (school fixed effects) }\end{array}$ \\
\hline \multicolumn{3}{|l|}{ Teacher characteristics } \\
\hline Member of union & $\begin{array}{c}0.3580^{*} \\
(2.33)\end{array}$ & $\begin{array}{c}0.1498^{*} \\
(2.26)\end{array}$ \\
\hline MA or PhD & $\begin{array}{l}0.0555^{* *} \\
(2.65)\end{array}$ & $\begin{array}{l}0.0401^{* *} \\
(2.84)\end{array}$ \\
\hline Teacher training & $\begin{array}{c}0.0697^{* *} \\
(3.39)\end{array}$ & $\begin{array}{c}0.0596^{* *} \\
(4.40)\end{array}$ \\
\hline First division in hsec exam & $\begin{array}{l}-0.0315 \\
(-1.00)\end{array}$ & $\begin{array}{c}0.0134 \\
(0.68)\end{array}$ \\
\hline Christian & $\begin{array}{c}0.0607^{*} \\
(2.25)\end{array}$ & $\begin{array}{c}0.0618^{* *} \\
(3.76)\end{array}$ \\
\hline Female & $\begin{array}{c}-0.0230 \\
(-0.93)\end{array}$ & $\begin{array}{l}-0.0013 \\
(-0.092)\end{array}$ \\
\hline Age & $\begin{array}{c}0.0546^{* *} \\
(8.08)\end{array}$ & $\begin{array}{c}0.0340^{* *} \\
(5.33)\end{array}$ \\
\hline Age square & $\begin{array}{c}-0.0005^{* *} \\
(-6.05)\end{array}$ & $\begin{array}{c}-0.0003^{* *} \\
(-3.57)\end{array}$ \\
\hline Subject dummies & yes & yes \\
\hline School variables & yes & --- \\
\hline State dummies & yes & --- \\
\hline $\mathrm{N}$ & 1731 & 1731 \\
\hline R-squared & 0.59 & 0.22 \\
\hline Number of scid_n & --- & 183 \\
\hline F (p-value) & --- & $35.43(0.000)$ \\
\hline Estimated Bias (Equation (8)) & 0.45 & 0.09 \\
\hline Ratio (a) & 0.89 & 1.65 \\
\hline
\end{tabular}

(a) This is the ratio of the coefficient on union membership and the estimated bias. 


\section{Table 7}

\section{Regression of log of teacher's monthly pay}

(including the teacher characteristics in $\mathrm{TC}^{\prime}$ )

(Teachers of grade 10 who teach the 5 main subjects only)

\begin{tabular}{|c|c|c|}
\hline & $\begin{array}{l}\text { Across school } \\
\text { (OLS) }\end{array}$ & $\begin{array}{c}\text { Within school } \\
\text { (school fixed effects) }\end{array}$ \\
\hline \multicolumn{3}{|l|}{ Teacher characteristics } \\
\hline Member of union & $\begin{array}{c}0.2932 * \\
(2.13)\end{array}$ & $\begin{array}{c}0.0947^{*} \\
(1.96)\end{array}$ \\
\hline MA or $\mathrm{PhD}$ & $\begin{array}{l}0.0681^{* *} \\
\quad(3.62)\end{array}$ & $\begin{array}{l}0.0530 * * \\
\quad(4.30)\end{array}$ \\
\hline Teacher training & $\begin{array}{c}0.0427 * \\
(2.19)\end{array}$ & $\begin{array}{l}0.0316^{* *} \\
(2.72)\end{array}$ \\
\hline First division in hsec exam & $\begin{array}{l}-0.0537 \\
(-1.77)\end{array}$ & $\begin{array}{l}-0.0036 \\
(-0.20)\end{array}$ \\
\hline Christian & $\begin{array}{l}0.0392 \\
(1.52)\end{array}$ & $\begin{array}{l}0.0397 * * \\
(2.85)\end{array}$ \\
\hline Female & $\begin{array}{c}-0.0218 \\
(-0.95)\end{array}$ & $\begin{array}{c}-0.0170 \\
(-1.29)\end{array}$ \\
\hline Age & $\begin{array}{l}0.0256^{* *} \\
(3.90)\end{array}$ & $\begin{array}{l}0.0107 \\
(1.79)\end{array}$ \\
\hline Age square & $\begin{array}{c}-0.0003^{* *} \\
(-3.68)\end{array}$ & $\begin{array}{c}-0.0001 \\
(-1.68)\end{array}$ \\
\hline Days of sick leave last year & $\begin{array}{c}-0.0073^{*} \\
(-2.14)\end{array}$ & $\begin{array}{c}-0.0007 \\
(-0.50)\end{array}$ \\
\hline Total experience & $\begin{array}{c}0.0061^{* *} \\
(2.85)\end{array}$ & $\begin{array}{c}0.0075^{* *} \\
(4.30)\end{array}$ \\
\hline Tenure & $\begin{array}{c}0.0133^{* *} \\
(6.68)\end{array}$ & $\begin{array}{l}0.0095^{* *} \\
(5.43)\end{array}$ \\
\hline Permanent contract & $\begin{array}{l}0.1756^{* *} \\
(5.46)\end{array}$ & $\begin{array}{l}0.1639 * * \\
(5.54)\end{array}$ \\
\hline Subject dummies & yes & yes \\
\hline School variables & yes & --- \\
\hline State dummies & yes & --- \\
\hline $\mathrm{N}$ & 1731 & 1731 \\
\hline R-squared & 0.65 & 0.39 \\
\hline Number of schools & --- & 183 \\
\hline F (p-value) & --- & $35.43(0.000)$ \\
\hline Estimated Bias (Equation (8)) & 0.44 & 0.08 \\
\hline Ratio (a) & 0.74 & 1.20 \\
\hline
\end{tabular}

(a) This is the ratio of the coefficient on union membership and the estimated bias.

Note: t-values are in parentheses and are robust to clustering at the school level. For School fixed-effects estimation, the number of groups is 183, i.e. estimation is within 183 schools. Mean number of teachers within a school is 9.5 (minimum=4, maximum=30). The F-test shows that the school dummies are jointly significant at the 0.000 level. Constant included but not shown. ** represents statistical significance at the $1 \%$ level and * at the $5 \%$ level. 


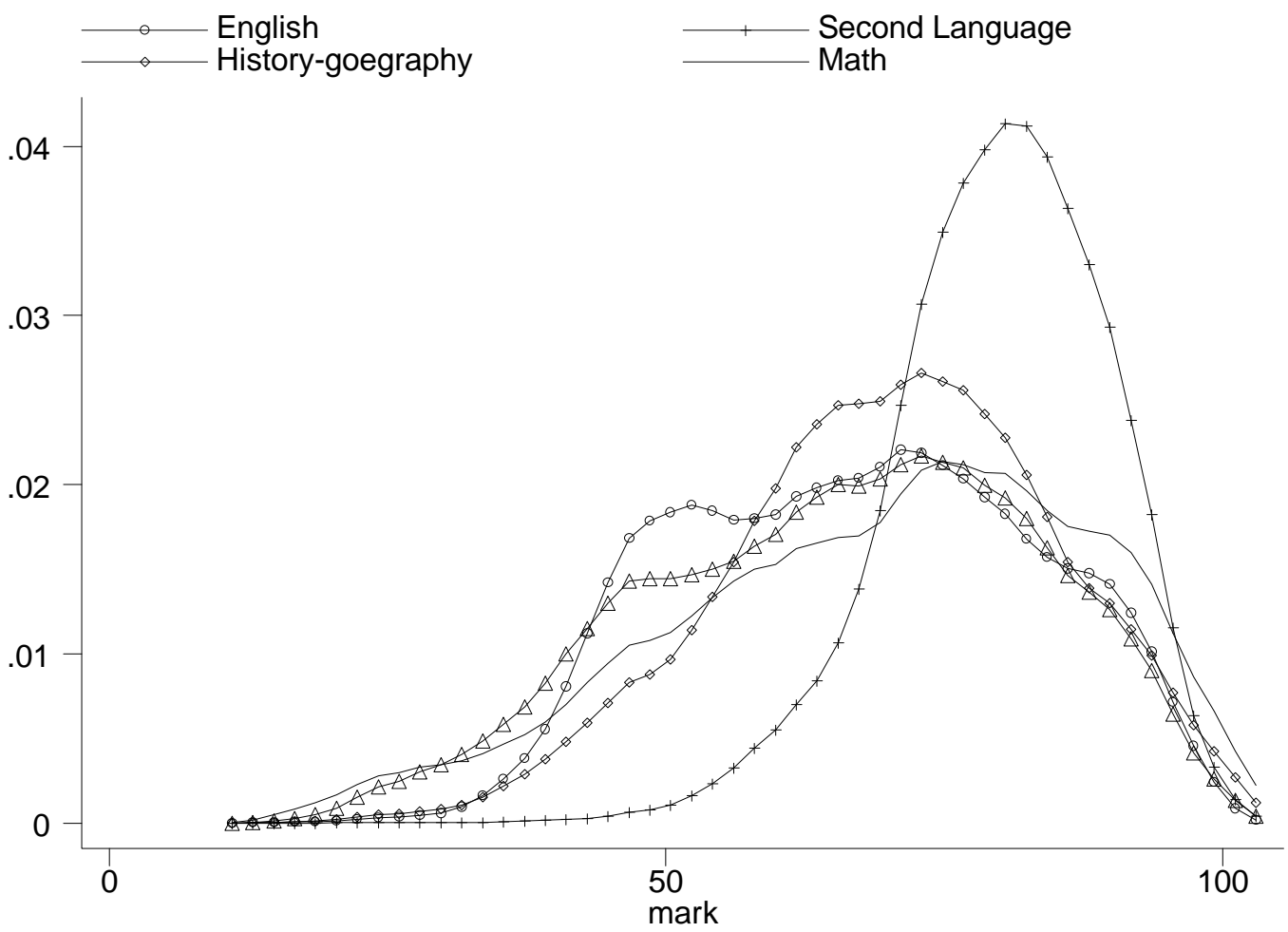

Figure 1: Distribution of raw marks, by subject

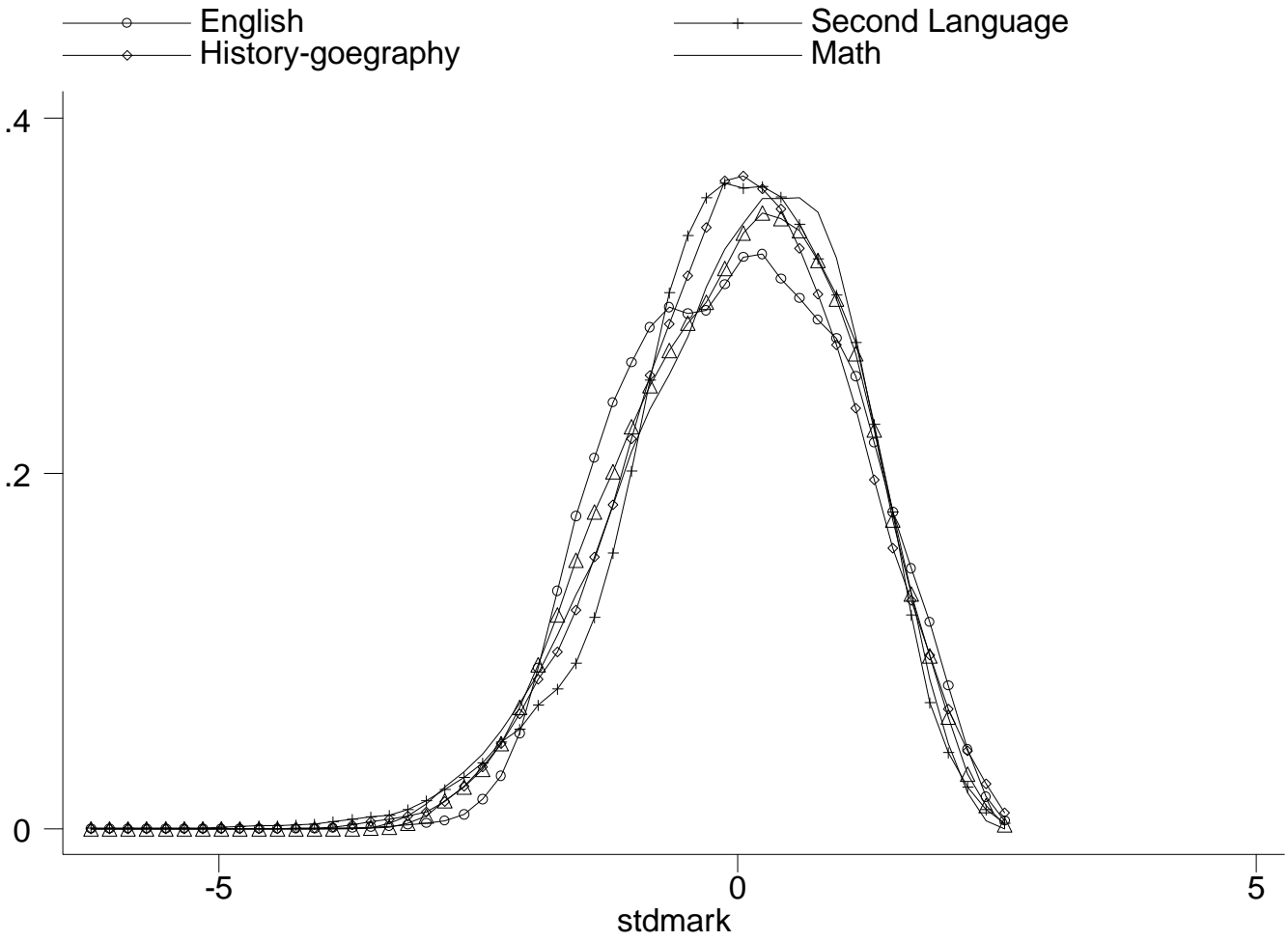

Figure 2: Distribution of standardized marks, by subject 


\section{Appendix}

\section{Selection on Unobservables}

In the Altonji, Elder and Taber (2005) paper the issue is to assess the potential importance of unobservables in a bivariate probit model of a school outcome $Y$ as a function of attending a catholic school $(\mathrm{CH})$. To gauge the role of selection bias in a simple way they ignore the fact that $Y$ is estimated by a probit and treat $\theta$ (the parameter of interest to establish the casual affect of catholic schooling on outcomes) as if it were estimated by a regression of the latent variable $Y^{*}$ on $X$ and $C H$ where $X$ is a vector of observable determinants of both the $Y$ and $C H$ variables. In our application the outcome, student achievement as measured by the standardised mark, is a continuous variable but that does not affect the logic of the approach.

We need to use an equation of the form:

$$
A=\theta \hat{U}+[\gamma+\theta \beta] T C+\varepsilon
$$

where we have dropped subscripts for clarity and

(A2) $U=\beta T C+\tilde{U}$

which is equivalent to estimating our equation of interest which is:

$$
A=\theta U+\gamma T C+\varepsilon
$$

By construction $\tilde{U}$ and $T C$ are orthogonal in (A1) and the standard formula for the potential bias in the $\theta$ parameter is

$$
P \lim \hat{\theta} \approx \theta+\frac{\operatorname{Cov}(\tilde{U}, \varepsilon)}{\operatorname{Var}(\tilde{U})}=\frac{\operatorname{Cov}(U, \varepsilon)}{\operatorname{Var}(\tilde{U})}
$$

The second equality follows from the fact that $\varepsilon$ and $T C$ are orthogonal.

The condition in the Altonji, Elder and Taber (2005) paper which defines the notion that "selection on the unobservables" is the same as selection on observables is equivalent to the condition that:

(A5) $\frac{\operatorname{Cov}(U, \varepsilon)}{\operatorname{Var}(\varepsilon)}=\frac{\operatorname{Cov}(\gamma T C, U)}{\operatorname{Var}(\gamma T C)}$

The bias in (A4) can be written as:

(A6) $\frac{\operatorname{Cov}(U, \varepsilon)}{\operatorname{Var}(\tilde{U})}=\frac{\operatorname{Cov}(U, \varepsilon)}{\operatorname{Cov}(\gamma T C, U)} \frac{\operatorname{Var}(\gamma T C)}{\operatorname{Var}(\varepsilon)} \frac{\operatorname{Cov}(\gamma T C, U)}{\operatorname{Var}(\gamma T C)} \frac{\operatorname{Var}(\varepsilon)}{\operatorname{Var}(\tilde{U})}$ 
Using (A5) this can be written as:

(A7) $\frac{\operatorname{Cov}(U, \varepsilon)}{\operatorname{Var}(\tilde{U})}=\frac{\operatorname{Cov}(\gamma T C, U)}{\operatorname{Var}(\gamma T C)} \frac{\operatorname{Var}(\varepsilon)}{\operatorname{Var}(\tilde{U})}$

In their paper Altonji et. al. are concerned that a positive bias could be induced by the positive covariance between $X$ and $\mathrm{CH}$. In our application of their procedure we are concerned with the correlation between $\gamma T C$ and $U$. In fact these are strongly positively correlated. This explains our argument in the text that selection on unobservables suggests that our estimation of the negative effect is a lower bound to the true negative effect of unionisation on student achievement. We report in Appendix Table A1 the results for both the student achievement mark and for union membership as a function of the $T C$ variables.

\section{Appendix Table A1}

Pupil fixed effects Linear probability model of union membership (union member $=1$; non-member $=0$ ) and of achievement score

\begin{tabular}{lcc}
\hline & Achievement score & Union membership \\
\hline & & \\
MA or PhD qualification & $(9.48)$ & $0.0050^{* *}$ \\
& $0.0805^{* *}$ & $(4.19)$ \\
Pre-service teacher training & $(9.39)$ & $0.0351^{* *}$ \\
& $0.1072^{* *}$ & $(19.67)$ \\
First division in hisec exam & $(7.65)$ & $-0.0088^{* *}$ \\
& $0.0297^{* *}$ & $(-3.60)$ \\
Christian & $(2.94)$ & $-0.0198^{* *}$ \\
& 0.0001 & $(-11.36)$ \\
Female & $(0.01)$ & $0.0085^{* *}$ \\
& $0.0262^{* *}$ & $(5.22)$ \\
Age & $(8.44)$ & $-0.0009^{* *}$ \\
& $-0.0003^{* *}$ & $(-4.89)$ \\
Age square & $(-7.93)$ & $0.0000^{* *}$ \\
& yes & $(6.54)$ \\
\hline Subject dummies & 49089 & yes \\
Observations & 10016 & 49089 \\
Number of clusters & & 10016 \\
& & \\
\hline
\end{tabular}


Appendix Table A2

Variable definitions and descriptive statistics

\begin{tabular}{|c|c|c|c|}
\hline Variable & Definition & Mean & SD \\
\hline \multicolumn{4}{|l|}{ Pupil characteristics } \\
\hline stdmark & Standardized mark & 0.000 & 1.00 \\
\hline Male & Child is male* & 0.491 & 0.50 \\
\hline Age in months & Child's age in months & 195.055 & 8.90 \\
\hline Age in months squared & Age squared & 38.126 & 3.56 \\
\hline No. younger brothers & Number of younger brothers & 0.418 & 0.60 \\
\hline No. of older brothers & Number of older brothers & 0.327 & 0.64 \\
\hline No. of younger sisters & Number of younger sisters & 0.333 & 0.57 \\
\hline No. of older sisters & Number of older sisters & 0.365 & 0.70 \\
\hline Father’s education & Father’s education in years & 14.886 & 2.32 \\
\hline Mother's education & Mother's education in years & 13.645 & 2.73 \\
\hline Wears spectacles & Child wears spectacles* & 0.282 & 0.45 \\
\hline Disabled & Child is disabled* & 0.003 & 0.06 \\
\hline Sibling in similar school & Any sibling studies in ICSE school & 0.301 & 0.46 \\
\hline Raven test score & Score on Raven’s ability test & 23.824 & 6.40 \\
\hline Hours per day study at home & Hours per day spent in study at home & 4.033 & 1.61 \\
\hline Hours per day domestic work & Hours per day spent in domestic work & 0.692 & 0.57 \\
\hline Hours per day play & Hours per day spent in playing & 1.631 & 0.86 \\
\hline Hours per day travel to school & Hours per day spent in travel to school & 0.614 & 0.48 \\
\hline Hours per day spent in school & Hours per day spent in school & 6.223 & 0.73 \\
\hline \multicolumn{4}{|l|}{$\underline{\text { Household characteristics }}$} \\
\hline Household size & Household size & 5.361 & 2.62 \\
\hline Religion Sikh & Religion is Sikh* & 0.058 & 0.23 \\
\hline Religion Christian & Religion is Christian* & 0.078 & 0.27 \\
\hline Religion Muslim & Religion is Muslim* & 0.069 & 0.25 \\
\hline Wealth index & Index of asset ownership & 21.629 & 6.31 \\
\hline Wealth index squared & Wealth squared & 507.608 & 256.85 \\
\hline Other backward caste & 'other backward caste’* & 0.062 & 0.24 \\
\hline Schedule caste & ‘scheduled caste’* & 0.012 & 0.11 \\
\hline Schedule tribe & 'scheduled tribe'* & 0.017 & 0.13 \\
\hline \multicolumn{4}{|l|}{$\underline{\text { Teacher characteristics }}$} \\
\hline Gross monthly pay & Teachers' gross monthly pay (Rupees) & 7864.421 & 2997.72 \\
\hline Log monthly pay & Log of teacher’s gross monthly pay & 8.884 & 0.40 \\
\hline MA or $\mathrm{PhD}$ & Teacher has MA/MSc/PhD* & 0.741 & 0.35 \\
\hline Teacher training & Years of teacher training & 0.920 & 0.36 \\
\hline First division in hisec exam & $\begin{array}{l}\text { Teacher got first division in Higher Secondary exam } \\
\text { (Proxy for teacher's cognitive skills) }\end{array}$ & 0.092 & 0.23 \\
\hline Days of sick leave & Days of sick leave taken by teacher last year & 2.182 & 2.70 \\
\hline Member of union & Teacher is member of a teacher union* & 0.036 & 0.16 \\
\hline Christian & Teacher is Christian* & 0.251 & 0.36 \\
\hline Female & Teacher is female* & 0.723 & 0.39 \\
\hline Age & Teacher’s age & 41.122 & 7.92 \\
\hline Age square & Teachers age squared & 1778.512 & 667.40 \\
\hline Total experience & Years of work experience in teaching & 13.388 & 7.17 \\
\hline
\end{tabular}


Tenure

Permanent contract

\section{School characteristics}

Total strength

Pupils in grade 10 (class size)

Principal influence index

Log monthly fee in grade 10

Girls school

Higher secondary school

Index of school resources
Years of work experience in this school

Teacher's contract is permanent?* Yes $=1 ;$ no $=0$

10.037

0.878

6.67

Total number of pupils in the school

1648.789

852.18

Number of pupils in grade 10

Index of principal's influence in school decision-

making: lowest $=1$, highest $=5$

111.175

59.55

Log of monthly fee (rupees)

4.161

0.93

Is a girls-only school*

6.349

0.48

Is a higher secondary school*

0.210

0.41

Index of school resources
0.567

0.50

20.598

Note: Variables marked with a * are $0 / 1$ indicator variables with yes $=1$ and no $=0$. The means of all variables (pupil, teacher and school) in this table have been computed using the pupil-subject level dataset. 


\section{Appendix Table A3 \\ OLS Achievement production function, by subject}

\begin{tabular}{|c|c|c|c|c|c|}
\hline & $\underline{\text { English }}$ & 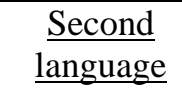 & $\begin{array}{l}\text { History- } \\
\text { geography }\end{array}$ & $\underline{\text { Math }}$ & $\underline{\text { Science }}$ \\
\hline \multicolumn{6}{|l|}{ Pupil characteristics } \\
\hline Male & $\begin{array}{l}-0.1686^{* *} \\
(-8.71)\end{array}$ & $\begin{array}{l}-0.3601^{* *} \\
(-16.1)\end{array}$ & $\begin{array}{l}-0.0148 \\
(-0.69)\end{array}$ & $\begin{array}{l}0.0367 \\
(1.74)\end{array}$ & $\begin{array}{l}0.0354 \\
(1.66)\end{array}$ \\
\hline Age in months & $\begin{array}{l}0.1287 * * \\
(6.63)\end{array}$ & $\begin{array}{l}0.0816^{* *} \\
(3.21)\end{array}$ & $\begin{array}{l}0.1469 * * \\
(6.34)\end{array}$ & $\begin{array}{l}0.1807 * * \\
(7.42)\end{array}$ & $\begin{array}{l}0.1752^{* *} \\
(7.26)\end{array}$ \\
\hline Age in months squared & $\begin{array}{l}-0.3505^{* *} \\
(-7.24)\end{array}$ & $\begin{array}{l}-0.2403^{* *} \\
(-3.77)\end{array}$ & $\begin{array}{l}-0.4093^{* *} \\
(-7.05)\end{array}$ & $\begin{array}{l}-0.4973^{* *} \\
(-8.14)\end{array}$ & $\begin{array}{l}-0.4862 * * \\
(-8.04)\end{array}$ \\
\hline No. younger brothers & $\begin{array}{l}-0.0478 * * \\
(-3.35)\end{array}$ & $\begin{array}{l}-0.0275 \\
(-1.59)\end{array}$ & $\begin{array}{l}-0.0205 \\
(-1.27)\end{array}$ & $\begin{array}{l}-0.0278 \\
(-1.66)\end{array}$ & $\begin{array}{l}-0.0308 \\
(-1.89)\end{array}$ \\
\hline No. of older brothers & $\begin{array}{l}-0.0392^{* *} \\
(-2.98)\end{array}$ & $\begin{array}{l}-0.0372 * \\
(-2.13)\end{array}$ & $\begin{array}{l}-0.0284 \\
(-1.89)\end{array}$ & $\begin{array}{l}-0.0270 \\
(-1.70)\end{array}$ & $\begin{array}{l}-0.0342 * \\
(-2.20)\end{array}$ \\
\hline No. of younger sisters & $\begin{array}{l}-0.0248 \\
(-1.66)\end{array}$ & $\begin{array}{l}-0.0355^{*} \\
(-1.99)\end{array}$ & $\begin{array}{l}-0.0180 \\
(-1.07)\end{array}$ & $\begin{array}{l}-0.0340^{*} \\
(-2.00)\end{array}$ & $\begin{array}{l}-0.0459 * * \\
(-2.70)\end{array}$ \\
\hline No. of older sisters & $\begin{array}{l}-0.0225 \\
(-1.85)\end{array}$ & $\begin{array}{l}0.0013 \\
(0.094)\end{array}$ & $\begin{array}{l}-0.0209 \\
(-1.51)\end{array}$ & $\begin{array}{l}-0.0155 \\
(-1.08)\end{array}$ & $\begin{array}{l}-0.0153 \\
(-1.08)\end{array}$ \\
\hline Father's education & $\begin{array}{l}0.0319 * * \\
(7.44)\end{array}$ & $\begin{array}{l}0.0201^{* *} \\
(3.90)\end{array}$ & $\begin{array}{l}0.0319 * * \\
(6.89)\end{array}$ & $\begin{array}{l}0.0305^{* *} \\
(6.37)\end{array}$ & $\begin{array}{l}0.0356^{* *} \\
(7.64)\end{array}$ \\
\hline Mother's education & $\begin{array}{l}0.0491 * * \\
(12.8)\end{array}$ & $\begin{array}{l}0.0193 * * \\
(4.44)\end{array}$ & $\begin{array}{l}0.0372 * * \\
(9.07)\end{array}$ & $\begin{array}{l}0.0376^{* *} \\
(8.77)\end{array}$ & $\begin{array}{l}0.0429 * * \\
(10.3)\end{array}$ \\
\hline Wears spectacles & $\begin{array}{l}0.1377 * * \\
(7.97)\end{array}$ & $\begin{array}{l}0.0778^{* *} \\
(4.06)\end{array}$ & $\begin{array}{l}0.1120^{* *} \\
(5.96)\end{array}$ & $\begin{array}{l}0.1191^{* *} \\
(6.27)\end{array}$ & $\begin{array}{l}0.1173^{* *} \\
(6.26)\end{array}$ \\
\hline Disabled & $\begin{array}{l}-0.0438 \\
(-0.43)\end{array}$ & $\begin{array}{l}-0.0703 \\
(-0.43)\end{array}$ & $\begin{array}{l}0.0018 \\
(0.012)\end{array}$ & $\begin{array}{l}-0.1633 \\
(-1.02)\end{array}$ & $\begin{array}{l}0.0622 \\
(0.40)\end{array}$ \\
\hline Sibling in similar school & $\begin{array}{l}0.0231 \\
(1.23)\end{array}$ & $\begin{array}{l}-0.0690^{* *} \\
(-3.10)\end{array}$ & $\begin{array}{l}0.0395 \\
(1.88)\end{array}$ & $\begin{array}{l}0.0396 \\
(1.85)\end{array}$ & $\begin{array}{l}0.0258 \\
(1.20)\end{array}$ \\
\hline Raven test score & $\begin{array}{l}0.0325^{* *} \\
(26.6)\end{array}$ & $\begin{array}{l}0.0253^{* *} \\
(17.1)\end{array}$ & $\begin{array}{l}0.0344^{* *} \\
(24.3)\end{array}$ & $\begin{array}{l}0.0438 * * \\
(30.1)\end{array}$ & $\begin{array}{l}0.0393^{* *} \\
(28.0)\end{array}$ \\
\hline Hours per day in study at home & $\begin{array}{l}-0.0045 \\
(-0.82)\end{array}$ & $\begin{array}{l}0.0033 \\
(0.54)\end{array}$ & $\begin{array}{l}-0.0069 \\
(-1.14)\end{array}$ & $\begin{array}{l}0.0174 * * \\
(2.89)\end{array}$ & $\begin{array}{l}0.0125^{*} \\
(2.08)\end{array}$ \\
\hline Hours per day in domestic work & $\begin{array}{l}-0.0557 * * \\
(-3.84)\end{array}$ & $\begin{array}{l}-0.0230 \\
(-1.35)\end{array}$ & $\begin{array}{l}-0.0728 * * \\
(-4.60)\end{array}$ & $\begin{array}{l}-0.0831 * * \\
(-5.11)\end{array}$ & $\begin{array}{l}-0.0818^{* * *} \\
(-5.06)\end{array}$ \\
\hline Hours per day in play & $\begin{array}{l}-0.0186 \\
(-1.95)\end{array}$ & $\begin{array}{l}-0.0128 \\
(-1.16)\end{array}$ & $\begin{array}{l}-0.0174 \\
(-1.63)\end{array}$ & $\begin{array}{l}-0.0245^{*} \\
(-2.23)\end{array}$ & $\begin{array}{l}-0.0277^{*} \\
(-2.54)\end{array}$ \\
\hline Hours per day in travel to school & $\begin{array}{l}0.0182 \\
(1.13)\end{array}$ & $\begin{array}{l}0.0046 \\
(0.24)\end{array}$ & $\begin{array}{l}-0.0070 \\
(-0.39)\end{array}$ & $\begin{array}{l}0.0212 \\
(1.16)\end{array}$ & $\begin{array}{l}0.0249 \\
(1.39)\end{array}$ \\
\hline Hours per day spent in school & $\begin{array}{l}-0.0016 \\
(-0.097)\end{array}$ & $\begin{array}{l}0.0478^{* *} \\
(2.40)\end{array}$ & $\begin{array}{l}0.0605^{* *} \\
(3.63)\end{array}$ & $\begin{array}{l}0.0484^{* *} \\
(2.63)\end{array}$ & $\begin{array}{l}0.0043 \\
(0.25)\end{array}$ \\
\hline Household characteristics & & & & & \\
\hline Household size & $\begin{array}{l}-0.0060 \\
(-1.86)\end{array}$ & $\begin{array}{l}-0.0001 \\
(-0.036)\end{array}$ & $\begin{array}{l}-0.0012 \\
(-0.33)\end{array}$ & $\begin{array}{l}-0.0025 \\
(-0.62)\end{array}$ & $\begin{array}{l}-0.0057 \\
(-1.50)\end{array}$ \\
\hline Religion Sikh & $\begin{array}{l}-0.1114^{* *} \\
(-2.80)\end{array}$ & $\begin{array}{l}-0.0976^{*} \\
(-2.19)\end{array}$ & $\begin{array}{l}-0.0785 \\
(-1.69)\end{array}$ & $\begin{array}{l}-0.1285^{* *} \\
(-2.77)\end{array}$ & $\begin{array}{l}-0.0610 \\
(-1.30)\end{array}$ \\
\hline Religion Christian & $\begin{array}{l}0.0575 \\
(1.72)\end{array}$ & $\begin{array}{l}-0.3537 * * \\
(-8.58)\end{array}$ & $\begin{array}{l}-0.0730 * \\
(-2.06)\end{array}$ & $\begin{array}{l}-0.2140 * * \\
(-5.62)\end{array}$ & $\begin{array}{l}-0.1927 * * \\
(-5.36)\end{array}$ \\
\hline Religion Muslim & $\begin{array}{l}-0.0240 \\
(-0.77)\end{array}$ & $\begin{array}{l}-0.1757 * * \\
(-4.69)\end{array}$ & $\begin{array}{l}-0.0824 * \\
(-2.42)\end{array}$ & $\begin{array}{l}-0.1598 * * \\
(-4.36)\end{array}$ & $\begin{array}{l}-0.1039 * * \\
(-2.95)\end{array}$ \\
\hline Wealth index & $\begin{array}{l}0.0132 * \\
(2.27)\end{array}$ & $\begin{array}{l}-0.0002 \\
(-0.027)\end{array}$ & $\begin{array}{l}0.0178 * * \\
(2.74)\end{array}$ & $\begin{array}{l}0.0216^{* *} \\
(3.23)\end{array}$ & $\begin{array}{l}0.0115 \\
(1.72)\end{array}$ \\
\hline
\end{tabular}




\begin{tabular}{|c|c|c|c|c|c|}
\hline Wealth index squared & $\begin{array}{l}-0.0004^{* *} \\
(-2.78)\end{array}$ & $\begin{array}{l}-0.0003 \\
(-1.74)\end{array}$ & $\begin{array}{l}-0.0006^{* *} \\
(-3.77)\end{array}$ & $\begin{array}{l}-0.0007 * * \\
(-4.26)\end{array}$ & $\begin{array}{l}-0.0005^{* *} \\
(-3.14)\end{array}$ \\
\hline Other Backward Caste & $\begin{array}{l}-0.0370 \\
(-1.09)\end{array}$ & $\begin{array}{l}-0.0069 \\
(-0.16)\end{array}$ & $\begin{array}{l}-0.1041^{* *} \\
(-2.79)\end{array}$ & $\begin{array}{l}-0.0980^{* *} \\
(-2.60)\end{array}$ & $\begin{array}{l}-0.0697 \\
(-1.90)\end{array}$ \\
\hline Schedule caste & $\begin{array}{l}0.0938 \\
(1.22)\end{array}$ & $\begin{array}{l}-0.0040 \\
(-0.046)\end{array}$ & $\begin{array}{l}-0.0011 \\
(-0.013)\end{array}$ & $\begin{array}{l}-0.0307 \\
(-0.37)\end{array}$ & $\begin{array}{l}0.0272 \\
(0.34)\end{array}$ \\
\hline Schedule tribe & $\begin{array}{l}-0.0917 \\
(-1.37)\end{array}$ & $\begin{array}{l}-0.0087 \\
(-0.11)\end{array}$ & $\begin{array}{l}-0.2323^{* *} \\
(-3.21)\end{array}$ & $\begin{array}{l}-0.2467^{* *} \\
(-3.29)\end{array}$ & $\begin{array}{l}-0.1752^{*} \\
(-2.48)\end{array}$ \\
\hline \multicolumn{6}{|l|}{ Teacher characteristics } \\
\hline Member of teacher union & $\begin{array}{l}0.1969 * * \\
(2.95)\end{array}$ & $\begin{array}{l}0.2667^{* *} \\
(4.08)\end{array}$ & $\begin{array}{l}0.0759 \\
(1.00)\end{array}$ & $\begin{array}{l}0.0614 \\
(1.00)\end{array}$ & $\begin{array}{l}-0.0124 \\
(-0.23)\end{array}$ \\
\hline Log of monthly pay & $\begin{array}{l}0.4612^{* *} \\
(11.2)\end{array}$ & $\begin{array}{l}0.3730 * * \\
(8.30)\end{array}$ & $\begin{array}{l}0.4346^{* *} \\
(9.67)\end{array}$ & $\begin{array}{l}0.2501^{* *} \\
(5.95)\end{array}$ & $\begin{array}{l}0.3740 * * \\
(8.45)\end{array}$ \\
\hline MA or PhD qualification & $\begin{array}{l}-0.0034 \\
(-0.11)\end{array}$ & $\begin{array}{l}0.1832 * * \\
(5.42)\end{array}$ & $\begin{array}{l}0.0407 \\
(1.23)\end{array}$ & $\begin{array}{l}0.0371 \\
(1.30)\end{array}$ & $\begin{array}{l}0.1737 * * \\
(4.16)\end{array}$ \\
\hline Pre-service teacher training & $\begin{array}{l}0.0181 \\
(0.67)\end{array}$ & $\begin{array}{l}0.0130 \\
(0.37)\end{array}$ & $\begin{array}{l}0.0572 \\
(1.74)\end{array}$ & $\begin{array}{l}0.0285 \\
(1.13)\end{array}$ & $\begin{array}{l}-0.0702 * \\
(-2.11)\end{array}$ \\
\hline First division in hisec exam & $\begin{array}{l}-0.0150 \\
(-0.32)\end{array}$ & $\begin{array}{l}0.2420 * * \\
(6.05)\end{array}$ & $\begin{array}{l}0.0332 \\
(0.66)\end{array}$ & $\begin{array}{l}-0.1088^{*} \\
(-2.43)\end{array}$ & $\begin{array}{l}-0.2201 * \\
(-2.39)\end{array}$ \\
\hline Days of sick leave last year & $\begin{array}{l}-0.0062 \\
(-1.63)\end{array}$ & $\begin{array}{l}-0.0134 * * \\
(-4.34)\end{array}$ & $\begin{array}{l}-0.0072 \\
(-1.81)\end{array}$ & $\begin{array}{l}-0.0157^{* *} \\
(-4.39)\end{array}$ & $\begin{array}{l}-0.0122 * * \\
(-2.65)\end{array}$ \\
\hline Christian & $\begin{array}{l}0.0729 * * \\
(3.16)\end{array}$ & $\begin{array}{l}0.1151^{* *} \\
(2.79)\end{array}$ & $\begin{array}{l}-0.1503^{* *} \\
(-4.69)\end{array}$ & $\begin{array}{l}-0.1309^{* *} \\
(-4.17)\end{array}$ & $\begin{array}{l}-0.0268 \\
(-0.67)\end{array}$ \\
\hline Female & $\begin{array}{l}0.0641^{*} \\
(2.07)\end{array}$ & $\begin{array}{l}0.0410 \\
(1.09)\end{array}$ & $\begin{array}{l}-0.1059 * * \\
(-3.66)\end{array}$ & $\begin{array}{l}-0.0588^{*} \\
(-2.27)\end{array}$ & $\begin{array}{l}0.0033 \\
(0.080)\end{array}$ \\
\hline Age & $\begin{array}{l}0.0035 \\
(0.42)\end{array}$ & $\begin{array}{l}-0.0108 \\
(-0.75)\end{array}$ & $\begin{array}{l}0.0221 \\
(1.58)\end{array}$ & $\begin{array}{l}0.0255^{*} \\
(2.08)\end{array}$ & $\begin{array}{l}-0.0057 \\
(-0.34)\end{array}$ \\
\hline Age square & $\begin{array}{l}-0.0001 \\
(-1.05)\end{array}$ & $\begin{array}{l}0.0001 \\
(0.89)\end{array}$ & $\begin{array}{l}-0.0002 \\
(-1.11)\end{array}$ & $\begin{array}{l}-0.0004 * \\
(-2.44)\end{array}$ & $\begin{array}{l}0.0000 \\
(0.080)\end{array}$ \\
\hline Total experience & $\begin{array}{l}0.0051^{*} \\
(2.03)\end{array}$ & $\begin{array}{l}-0.0003 \\
(-0.15)\end{array}$ & $\begin{array}{l}-0.0210^{* *} \\
(-7.22)\end{array}$ & $\begin{array}{l}0.0106^{* *} \\
(4.00)\end{array}$ & $\begin{array}{l}0.0180 * * \\
(4.34)\end{array}$ \\
\hline Tenure & $\begin{array}{l}-0.0043 \\
(-1.76)\end{array}$ & $\begin{array}{l}-0.0036 \\
(-1.74)\end{array}$ & $\begin{array}{l}-0.0079 * * \\
(-3.05)\end{array}$ & $\begin{array}{l}-0.0037 \\
(-1.73)\end{array}$ & $\begin{array}{l}-0.0046 \\
(-1.24)\end{array}$ \\
\hline Permanent status & $\begin{array}{l}-0.0047 \\
(-0.15)\end{array}$ & $\begin{array}{l}0.5208^{* *} \\
(7.78)\end{array}$ & $\begin{array}{l}0.2888 * * \\
(6.33)\end{array}$ & $\begin{array}{l}0.1260^{* *} \\
(3.24)\end{array}$ & $\begin{array}{l}0.0506 \\
(1.21)\end{array}$ \\
\hline \multicolumn{6}{|l|}{ School characteristics } \\
\hline Total strength & $\begin{array}{l}0.0001^{* *} \\
(6.69)\end{array}$ & $\begin{array}{l}0.0001 * * \\
(5.90)\end{array}$ & $\begin{array}{l}0.0002 * * \\
(8.94)\end{array}$ & $\begin{array}{l}0.0003^{* *} \\
(13.4)\end{array}$ & $\begin{array}{l}0.0002 * * \\
(10.3)\end{array}$ \\
\hline Pupils (class-size) in grade 10 & $\begin{array}{l}-0.0008^{*} \\
(-2.40)\end{array}$ & $\begin{array}{l}-0.0013^{* *} \\
(-3.78)\end{array}$ & $\begin{array}{l}-0.0013^{* *} \\
(-3.93)\end{array}$ & $\begin{array}{l}-0.0030^{* *} \\
(-8.73)\end{array}$ & $\begin{array}{l}-0.0020^{* *} \\
(-6.32)\end{array}$ \\
\hline Principal influence index & $\begin{array}{l}0.0537 * * \\
(4.94)\end{array}$ & $\begin{array}{l}0.0672 * * \\
(5.12)\end{array}$ & $\begin{array}{l}0.0733 * * \\
(5.68)\end{array}$ & $\begin{array}{l}0.0453 * * \\
(3.84)\end{array}$ & $\begin{array}{l}0.0353 * * \\
(3.02)\end{array}$ \\
\hline Log monthly fee in grade 10 & $\begin{array}{l}0.0875^{* *} \\
(3.24)\end{array}$ & $\begin{array}{l}-0.0004 \\
(-0.013)\end{array}$ & $\begin{array}{l}-0.1131^{* *} \\
(-3.88)\end{array}$ & $\begin{array}{l}-0.0595 * \\
(-2.12)\end{array}$ & $\begin{array}{l}-0.0400 \\
(-1.44)\end{array}$ \\
\hline Girls school & $\begin{array}{l}0.3391 * * \\
(13.4)\end{array}$ & $\begin{array}{l}0.0198 \\
(0.69)\end{array}$ & $\begin{array}{l}0.1826^{* *} \\
(6.45)\end{array}$ & $\begin{array}{l}0.1326^{* *} \\
(4.35)\end{array}$ & $\begin{array}{l}0.1479 * * \\
(4.95)\end{array}$ \\
\hline Higher secondary school & $\begin{array}{l}-0.0987^{* *} \\
(-4.99)\end{array}$ & $\begin{array}{l}-0.0533^{*} \\
(-2.27)\end{array}$ & $\begin{array}{l}-0.0588^{* *} \\
(-2.74)\end{array}$ & $\begin{array}{l}0.0592^{* *} \\
(2.77)\end{array}$ & $\begin{array}{l}-0.0034 \\
(-0.15)\end{array}$ \\
\hline Index of school resources & $\begin{array}{l}0.0136^{* *} \\
(14.1)\end{array}$ & $\begin{array}{l}-0.0001 \\
(-0.043)\end{array}$ & $\begin{array}{l}0.0075^{* *} \\
(6.88)\end{array}$ & $\begin{array}{l}0.0044^{* *} \\
(4.18)\end{array}$ & $\begin{array}{l}0.0049 * * \\
(4.76)\end{array}$ \\
\hline \multicolumn{6}{|l|}{ State dummies } \\
\hline Andhra Pradesh & $\begin{array}{l}-0.3024^{* *} \\
(-5.05)\end{array}$ & $\begin{array}{l}-0.8926^{* *} \\
(-11.6)\end{array}$ & $\begin{array}{l}-0.4498^{* *} \\
(-7.20)\end{array}$ & $\begin{array}{l}-0.3454^{* *} \\
(-5.34)\end{array}$ & $\begin{array}{l}-0.2704^{* *} \\
(-4.35) \\
\end{array}$ \\
\hline
\end{tabular}




\begin{tabular}{|c|c|c|c|c|c|}
\hline Bihar & $\begin{array}{l}-0.5308^{* *} \\
(-9.15)\end{array}$ & $\begin{array}{l}-0.2934^{* *} \\
(-3.89)\end{array}$ & $\begin{array}{l}-0.3865^{* *} \\
(-6.06)\end{array}$ & $\begin{array}{l}-0.1288 \\
(-1.86)\end{array}$ & $\begin{array}{l}-0.2684^{* *} \\
(-3.66)\end{array}$ \\
\hline Gujarat & $\begin{array}{l}-0.7744^{* *} \\
(-8.71)\end{array}$ & $\begin{array}{l}-0.9335^{* *} \\
(-8.74)\end{array}$ & $\begin{array}{l}-0.6923^{* * *} \\
(-6.71)\end{array}$ & $\begin{array}{l}-0.3956^{* *} \\
(-4.00)\end{array}$ & $\begin{array}{l}-0.3686 * * \\
(-4.05)\end{array}$ \\
\hline Haryana & $\begin{array}{l}-0.8423^{* *} \\
(-14.1)\end{array}$ & $\begin{array}{l}-1.0750 * * \\
(-14.9)\end{array}$ & $\begin{array}{l}-0.4381^{* *} \\
(-6.30)\end{array}$ & $\begin{array}{l}-0.2394 * * \\
(-3.34)\end{array}$ & $\begin{array}{l}-0.4024 * * \\
(-5.48)\end{array}$ \\
\hline Himachal & $\begin{array}{l}-0.3235^{* *} \\
(-5.56)\end{array}$ & $\begin{array}{l}-0.6683^{* *} \\
(-9.31)\end{array}$ & $\begin{array}{l}-0.1949 * * \\
(-3.15)\end{array}$ & $\begin{array}{l}-0.3302^{* *} \\
(-5.18)\end{array}$ & $\begin{array}{l}-0.3363^{* *} \\
(-5.28)\end{array}$ \\
\hline Karnataka & $\begin{array}{l}-0.3213^{* *} \\
(-6.00)\end{array}$ & $\begin{array}{l}-1.1284^{* *} \\
(-16.4)\end{array}$ & $\begin{array}{l}-0.2983^{* *} \\
(-5.13)\end{array}$ & $\begin{array}{l}-0.4948^{* *} \\
(-8.18)\end{array}$ & $\begin{array}{l}-0.4173^{* *} \\
(-6.91)\end{array}$ \\
\hline Maharashtra & $\begin{array}{l}-0.6101^{* *} \\
(-11.2)\end{array}$ & $\begin{array}{l}-0.9220 * * \\
(-12.6)\end{array}$ & $\begin{array}{l}-0.4095^{* *} \\
(-6.25)\end{array}$ & $\begin{array}{l}-0.4357 * * \\
(-6.75)\end{array}$ & $\begin{array}{l}-0.4213^{* *} \\
(-6.57)\end{array}$ \\
\hline Madhya Pradesh & $\begin{array}{l}-1.0217^{* *} \\
(-15.3)\end{array}$ & $\begin{array}{l}-0.9566^{* *} \\
(-12.5)\end{array}$ & $\begin{array}{l}-0.8276^{* *} \\
(-11.5)\end{array}$ & $\begin{array}{l}-0.5693^{* *} \\
(-7.51)\end{array}$ & $\begin{array}{l}-0.6783^{* *} \\
(-9.46)\end{array}$ \\
\hline Orissa & $\begin{array}{l}-0.3292^{* *} \\
(-5.98)\end{array}$ & $\begin{array}{l}-0.5465^{* *} \\
(-8.27)\end{array}$ & $\begin{array}{l}-0.2795^{* *} \\
(-4.85)\end{array}$ & $\begin{array}{l}-0.1355^{*} \\
(-2.19)\end{array}$ & $\begin{array}{l}-0.3109^{* *} \\
(-5.00)\end{array}$ \\
\hline Punjab & $\begin{array}{l}-0.8400^{* *} \\
(-13.8)\end{array}$ & $\begin{array}{l}-0.6425^{* * *} \\
(-8.75)\end{array}$ & $\begin{array}{l}-0.4538 * * \\
(-6.54)\end{array}$ & $\begin{array}{l}-0.3788 * * \\
(-5.62)\end{array}$ & $\begin{array}{l}-0.5958^{* *} \\
(-8.42)\end{array}$ \\
\hline Rajasthan & $\begin{array}{l}-0.8771^{* *} \\
(-10.5)\end{array}$ & $\begin{array}{l}-0.8967 * * \\
(-8.95)\end{array}$ & $\begin{array}{l}-0.0721 \\
(-0.84)\end{array}$ & $\begin{array}{l}-0.3362^{* *} \\
(-3.37)\end{array}$ & $\begin{array}{l}-0.4704^{* *} \\
(-4.69)\end{array}$ \\
\hline Tamil Nadu & $\begin{array}{l}-0.3212^{* * *} \\
(-4.78)\end{array}$ & $\begin{array}{l}-0.3762^{* * *} \\
(-4.31)\end{array}$ & $\begin{array}{l}-0.2887 * * \\
(-3.66)\end{array}$ & $\begin{array}{l}-0.1803 * \\
(-2.48)\end{array}$ & $\begin{array}{l}-0.1857 * * \\
(-2.60)\end{array}$ \\
\hline Uttar Pradesh & $\begin{array}{l}-0.8643^{* *} \\
(-16.8)\end{array}$ & $\begin{array}{l}-0.8614^{* *} \\
(-13.9)\end{array}$ & $\begin{array}{l}-0.7276^{* *} \\
(-12.9)\end{array}$ & $\begin{array}{l}-0.5292^{* *} \\
(-8.86)\end{array}$ & $\begin{array}{l}-0.7383^{* *} \\
(-12.1)\end{array}$ \\
\hline West Bengal & $\begin{array}{l}-0.4901 * * \\
(-9.36)\end{array}$ & $\begin{array}{l}-1.0550^{* * *} \\
(-16.1)\end{array}$ & $\begin{array}{l}-0.5533^{* *} \\
(-9.27)\end{array}$ & $\begin{array}{l}-0.4222^{* *} \\
(-7.01)\end{array}$ & $\begin{array}{l}-0.5451^{* *} \\
(-8.98)\end{array}$ \\
\hline Chattisgarh & $\begin{array}{l}-0.8375^{* *} \\
(-11.0)\end{array}$ & $\begin{array}{l}-1.0733^{* *} \\
(-9.78)\end{array}$ & $\begin{array}{l}-0.7433^{* *} \\
(-7.16)\end{array}$ & $\begin{array}{l}-0.7562^{* *} \\
(-7.40)\end{array}$ & $\begin{array}{l}-0.6671^{* *} \\
(-6.13)\end{array}$ \\
\hline _constant & $\begin{array}{l}-18.3856^{* *} \\
(-9.26)\end{array}$ & $\begin{array}{l}-11.1105^{* *} \\
(-4.35)\end{array}$ & $\begin{array}{l}-18.9495^{* *} \\
(-8.17)\end{array}$ & $\begin{array}{l}-21.2663^{* *} \\
(-8.70)\end{array}$ & $\begin{array}{l}-20.7108^{* *} \\
(-8.54)\end{array}$ \\
\hline Observations & 9772 & 9864 & 9833 & 9903 & 9717 \\
\hline R-squared & 0.44 & 0.24 & 0.33 & 0.30 & 0.33 \\
\hline
\end{tabular}

Note: the standard errors and thus t-values are corrected for the correlation of the errors between pupils within a school, i.e. we have used the pupil id as the clustering variable. The reference category for State is Kerala. 


\section{CESifo Working Paper Series}

for full list see www.cesifo-group.org/wp

(address: Poschingerstr. 5, 81679 Munich, Germany, office@cesifo.de)

2365 Stefan Voigt, The (Economic) Effects of Lay Participation in Courts - A Cross-Country Analysis, August 2008

2366 Tobias König and Andreas Wagener, (Post-)Materialist Attitudes and the Mix of Capital and Labour Taxation, August 2008

2367 Ximing Wu, Andreas Savvides and Thanasis Stengos, The Global Joint Distribution of Income and Health, August 2008

2368 Alejandro Donado and Klaus Wälde, Trade Unions Go Global!, August 2008

2369 Hans Gersbach and Hans Haller, Exit and Power in General Equilibrium, August 2008

2370 Jan P.A.M. Jacobs and Jan-Egbert Sturm, The Information Content of KOF Indicators on Swiss Current Account Data Revisions, August 2008

2371 Oliver Hülsewig, Johannes Mayr and Timo Wollmershäuser, Forecasting Euro Area Real GDP: Optimal Pooling of Information, August 2008

2372 Tigran Poghosyan and Jakob de Haan, Determinants of Cross-Border Bank Acquisitions in Transition Economies: A Latent Class Analysis, August 2008

2373 David Anthoff and Richard S.J. Tol, On International Equity Weights and National Decision Making on Climate Change, August 2008

2374 Florian Englmaier and Arno Schmöller, Reserve Price Formation in Online Auctions, August 2008

2375 Karl Farmer, Birgit Friedl and Andreas Rainer, Effects of Unilateral Climate Policy on Terms of Trade, Capital Accumulation, and Welfare in a World Economy, August 2008

2376 Monika Bütler, Stefan Staubli and Maria Grazia Zito, The Role of the Annuity's Value on the Decision (Not) to Annuitize: Evidence from a Large Policy Change, August 2008

2377 Inmaculada Martínez-Zarzoso, The Impact of Urbanization on $\mathrm{CO}_{2}$ Emissions: Evidence from Developing Countries, August 2008

2378 Brian Roberson and Dmitriy Kvasov, The Non-Constant-Sum Colonel Blotto Game, August 2008

2379 Ian Dew-Becker, How Much Sunlight Does it Take to Disinfect a Boardroom? A Short History of Executive Compensation Regulation, August 2008

2380 Cécile Aubert, Oliver Falck and Stephan Heblich, Subsidizing National Champions: An Evolutionary Perspective, August 2008 
2381 Sebastian Buhai, Miguel Portela, Coen Teulings and Aico van Vuuren, Returns to Tenure or Seniority?, August 2008

2382 Erkki Koskela and Jan König, Flexible Outsourcing, Profit Sharing and Equilibrium Unemployment, August 2008

2383 Torberg Falch and Justina AV Fischer, Does a Generous Welfare State Crowd out Student Achievement? Panel Data Evidence from International Student Tests, September 2008

2384 Pedro Gomes and François Pouget, Corporate Tax Competition and the Decline of Public Investment, September 2008

2385 Marko Koethenbuerger, How Do Local Governments Decide on Public Policy in Fiscal Federalism? Tax vs. Expenditure Optimization, September 2008

2386 Ronald McKinnon and Gunther Schnabl, China's Exchange Rate Impasse and the Weak U.S. Dollar, September 2008

2387 Yan-Leung Cheung, Yin-Wong Cheung and Alan T.K. Wan, A High-Low Model of Daily Stock Price Ranges, September 2008

2388 Louis Eeckhoudt and Harris Schlesinger, Changes in Risk and the Demand for Saving, September 2008

2389 Carsten Hefeker and Blandine Zimmer, Uncertainty and Fiscal Policy in an Asymmetric Monetary Union, September 2008

2390 Jay Pil Choi and Byung-Cheol Kim, Net Neutrality and Investment Incentives, September 2008

2391 Marcel Gérard, Financing Bologna, the Internationally Mobile Students in European Higher Education, September 2008

2392 Annette Alstadsæter and Knut Reidar Wangen, Corporations' Choice of Tax Regime when Transition Costs are Small and Income Shifting Potential is Large, September 2008

2393 António Afonso and Christophe Rault, 3-Step Analysis of Public Finances Sustainability: the Case of the European Union, September 2008

2394 Betsey Stevenson and Justin Wolfers, Economic Growth and Subjective Well-Being: Reassessing the Easterlin Paradox, September 2008

2395 Bernhard Eckwert and Itzhak Zilcha, Private Investment in Higher Education: Comparing Alternative Funding Schemes, September 2008

2396 Øystein Foros, Hans Jarle Kind and Jan Yngve Sand, Slotting Allowances and Manufacturers' Retail Sales Effort, September 2008 
2397 Mohammad Reza Farzanegan, Illegal Trade in the Iranian Economy: Evidence from a Structural Model, September 2008

2398 Olivier Bos, Charity Auctions for the Happy Few, September 2008

2399 Robert S. Chirinko and Debdulal Mallick, The Marginal Product of Capital: A Persistent International Puzzle, September 2008

2400 Ben D'Exelle and Arno Riedl, Elite Capture, Political Voice and Exclusion from Aid: An Experimental Study, September 2008

2401 Torben M. Andersen and Joydeep Bhattacharya, On Myopia as Rationale for Social Security, September 2008

2402 Fabienne Llense, French CEO Compensations: What is the Cost of a Mandatory Upper Limit?, September 2008

2403 Valentina Bosetti, Carlo Carraro, Alessandra Sgobbi and Massimo Tavoni, Delayed Action and Uncertain Targets. How Much Will Climate Policy Cost?, September 2008

2404 Robert G. Chambers, Rolf Färe, Shawna Grosskopf and Michael Vardanyan, Generalized Quadratic Revenue Functions, September 2008

2405 Leonidas Enrique de la Rosa, Overconfidence in a Career-Concerns Setting, September 2008

2406 Marcus Drometer and Johannes Rincke, The Design of Political Institutions: Electoral Competition and the Choice of Ballot Access Restrictions in the United States, September 2008

2407 Markku Lanne and Helmut Lütkepohl, Stock Prices and Economic Fluctuations: A Markov Switching Structural Vector Autoregressive Analysis, September 2008

2408 Thomas L. Brewer, International Energy Technology Transfers for Climate Change Mitigations, September 2008

2409 Alexander Kemnitz, Native Welfare Losses from High Skilled Immigration, September 2008

2410 Xavier Vives, Strategic Supply Function Competition with Private Information, September 2008

2411 Fabio Padovano and Roberto Ricciuti, The Political Competition-Economic Performance Puzzle: Evidence from the OECD Countries and the Italian Regions, September 2008

2412 Joan Costa-Font and Mireia Jofre-Bonet, Body Image and Food Disorders: Evidence from a Sample of European Women, September 2008

2413 Thorsten Upmann, Labour Unions - To Unite or to Separate?, October 2008 
2414 Sascha O. Becker and Ludger Woessmann, Luther and the Girls: Religious Denomination and the Female Education Gap in $19^{\text {th }}$ Century Prussia, October 2008

2415 Florian Englmaier and Stephen Leider, Contractual and Organizational Structure with Reciprocal Agents, October 2008

2416 Vittorio Daniele and Ugo Marani, Organized Crime and Foreign Direct Investment: The Italian Case, October 2008

2417 Valentina Bosetti, Carlo Carraro, Alessandra Sgobbi and Massimo Tavoni, Modelling Economic Impacts of Alternative International Climate Policy Architectures. A Quantitative and Comparative Assessment of Architectures for Agreement, October 2008

2418 Paul De Grauwe, Animal Spirits and Monetary Policy, October 2008

2419 Guglielmo Maria Caporale, Christophe Rault, Robert Sova and Anamaria Sova, On the Bilateral Trade Effects of Free Trade Agreements between the EU-15 and the CEEC-4 Countries, October 2008

2420 Yin-Wong Cheung and Daniel Friedman, Speculative Attacks: A Laboratory Study in Continuous Time, October 2008

2421 Kamila Fialová and Ondřej Schneider, Labour Market Institutions and their Effect on Labour Market Performance in the New EU Member Countries, October 2008

2422 Alexander Ludwig and Michael Reiter, Sharing Demographic Risk - Who is Afraid of the Baby Bust?, October 2008

2423 Doina Maria Radulescu and Michael Stimmelmayr, The Welfare Loss from Differential Taxation of Sectors in Germany, October 2008

2424 Nikolaus Wolf, Was Germany ever United? Evidence from Intra- and International Trade 1885 - 1933, October 2008

2425 Bruno S. Frey, David A. Savage and Benno Torgler, Noblesse Oblige? Determinants of Survival in a Life and Death Situation, October 2008

2426 Giovanni Facchini, Peri Silva and Gerald Willmann, The Customs Union Issue: Why do we Observe so few of them?, October 2008

2427 Wido Geis, Silke Uebelmesser and Martin Werding, Why go to France or Germany, if you could as well go to the UK or the US? Selective Features of Immigration to four major OECD Countries, October 2008

2428 Geeta Kingdon and Francis Teal, Teacher Unions, Teacher Pay and Student Performance in India: A Pupil Fixed Effects Approach, October 2008 